\title{
Effects of dust aerosols on tropospheric chemistry during a typical pre-monsoon season dust storm in northern India
}

\author{
R. Kumar ${ }^{1,2}$, M. C. Barth ${ }^{2}$, S. Madronich ${ }^{2}$, M. Naja $^{3}$, G. R. Carmichael ${ }^{4}$, G. G. Pfister ${ }^{2}$, C. Knote ${ }^{2}$, G. P. Brasseur ${ }^{1,5}$, \\ N. Ojha ${ }^{3}$, and T. Sarangi ${ }^{3}$ \\ ${ }^{1}$ Advanced Study Program, National Center for Atmospheric Research, Boulder, CO, USA \\ ${ }^{2}$ Atmospheric Chemistry Division, National Center for Atmospheric Research, Boulder, CO, USA \\ ${ }^{3}$ Aryabhatta Research Institute of Observational Sciences, Nainital, India \\ ${ }^{4}$ Center for Global and Regional Environmental Research, University of Iowa, Iowa City, IA 52242, USA \\ ${ }^{5}$ Climate Service Center, Helmholtz-Zentrum Geesthacht, Hamburg, Germany \\ Correspondence to: R. Kumar (rkumar@ucar.edu)
}

Received: 25 October 2013 - Published in Atmos. Chem. Phys. Discuss.: 14 January 2014

Revised: 23 April 2014 - Accepted: 22 May 2014 - Published: 4 July 2014

\begin{abstract}
This study examines the effect of a typical pre-monsoon season dust storm on tropospheric chemistry through a case study in northern India. Dust can alter photolysis rates by scattering and absorbing solar radiation and provide surface area for heterogeneous reactions. We use the Weather Research and Forecasting model coupled with Chemistry (WRF-Chem) to simulate the dust storm that occurred during 17-22 April 2010 and investigate the contribution of different processes on mixing ratios of several key trace gases including ozone, nitrogen oxides, hydrogen oxides, methanol, acetic acid and formaldehyde. We revised the Fast Troposphere Ultraviolet Visible (F-TUV) photolysis scheme to include effects of dust aerosols on photolysis rates in a manner consistent with the calculations of aerosol optical properties for feedback to the meteorology radiation schemes. In addition, we added 12 heterogeneous reactions on the dust surface, for which 6 reactions have relative-humidity-dependent reactive uptake coefficients $(\gamma)$. The inclusion of these processes in WRF-Chem is found to reduce the difference between observed and modeled $\mathrm{O}_{3}$ from $16 \pm 9$ to $2 \pm 8$ ppbv and that in $\mathrm{NO}_{\mathrm{y}}$ from $2129 \pm 1425$ to $372 \pm 1225$ pptv compared to measurements at the highaltitude site Nainital in the central Himalayas, and reduce biases by up to $30 \%$ in tropospheric column $\mathrm{NO}_{2}$ compared to OMI retrievals. The simulated dust storm acted as a sink for all the trace gases examined here and significantly perturbed their spatial and vertical distributions. The reductions in these gases are estimated as 5-100\%, and more than $80 \%$
\end{abstract}

of this reduction was due to heterogeneous chemistry. The RH dependence of $\gamma$ is also found to have substantial impact on the distribution of trace gases, with changes of up to 20$25 \%$ in $\mathrm{O}_{3}$ and $\mathrm{HO}_{2}, 50 \%$ in $\mathrm{H}_{2} \mathrm{O}_{2}$ and $100 \%$ in $\mathrm{HNO}_{3}$. A set of sensitivity analyses revealed that dust aging could change $\mathrm{H}_{2} \mathrm{O}_{2}$ and $\mathrm{CH}_{3} \mathrm{COOH}$ levels by up to $50 \%$ but has a relatively small impact on other gases.

\section{Introduction}

Dust aerosols have gained considerable attention in the recent years not only because they constitute a major fraction of the particulate matter in the troposphere but also because they have important implications for air quality, visibility, the earth's radiation budget (e.g., Haywood and Boucher, 2000; Seinfeld et al., 2004), biogeochemistry (e.g., Jickells et al., 2005), hydrological cycles (e.g., Miller et al., 2004; Zhao et al., 2011), and atmospheric chemistry (e.g., Dentener et al., 1996; Wang et al., 2012). The significance of dust aerosols for atmospheric chemistry has been manifested through several experimental (e.g., Goodman et al., 2000; Underwood et al., 2001; Li et al., 2006; Preszler Prince et al., 2007; Wagner et al., 2008; Cwiertny et al., 2008; Pradhan et al., 2010; Crowley et al., 2010; Chen et al., 2011; Bedjanian et al., 2013a, b) and modeling studies (e.g., Zhang et al., 1994; Dentener et al., 1996; Zhang and Carmichael, 1999; Tang et al., 2004; Martin et al., 2003; Bauer et al., 2004; Tie et al., 
2005; Hodzic et al., 2006; Zhu et al., 2010; Wang et al., 2012) during the past 2 decades.

Dust aerosols can influence atmospheric chemistry by affecting the photolysis rate coefficients through interaction with incoming solar radiation and by providing surface area for heterogeneous chemistry and deposition of different trace gases. It has been suggested that mineral dust aerosols are responsible for $5-20 \%$ reduction in photolysis rate coefficients of ozone $\left(\mathrm{O}_{3}\right)$ and nitrogen dioxide $\left(\mathrm{NO}_{2}\right)$ throughout the Northern Hemisphere (e.g., Martin et al., 2003; Tie et al., 2005; Ying et al., 2011). These changes in photolysis rate coefficients then decrease the annual mean global concentration of hydroxyl radical $(\mathrm{OH})$ by $9 \%$, which in turn leads to increases in the concentrations of several volatile organic compounds (Martin et al., 2003). Heterogeneous reactions on dust surfaces generally reduce the concentration of key atmospheric trace gases such as $\mathrm{O}_{3}$, nitrogen oxides, sulfur oxides and hydrogen oxides, but the amount of reported reduction in these gases varies widely, indicating that heterogeneous chemistry on dust surfaces is still not well understood. For example, the decreases in surface $\mathrm{O}_{3}$ are reported as 5$40 \%$ by different studies (Zhang et al., 1994; Dentener et al., 1996; Zhang and Carmichael, 1999; Tang et al., 2004; Bauer et al., 2004; Zhu et al., 2010; Wang et al., 2012). Likewise, the decreases for sulfur dioxide $\left(\mathrm{SO}_{2}\right)$, nitrogen oxides and hydrogen oxides are reported as 10-50, 16-100 and 11-59\% respectively.

Even though this study is focused on the impact of heterogeneous processes on dust surfaces on the tropospheric chemistry in northern India, it is worth mentioning other implications of heterogeneous chemistry here. The heterogeneous uptake of trace gases can potentially affect the physiochemical properties of dust aerosols and enhance their ability to act as cloud condensation nuclei (CCN). Dust particles are generally hydrophobic when they are emitted but become hygroscopic as they travel in the atmosphere and become coated with nitrate, sulfate and organics (e.g., Levin et al., 1996; Kelly et al., 2007; Hatch et al., 2008). The coating process will also modify the distributions of dust as well as sulfate and nitrate aerosols, which in turn will increase the scattering of solar radiation by aerosols. The increase in size of dust particles due to coating will increase the probability of their removal from the atmosphere, and such coated particles will experience less long-range transport.

Box and regional modeling studies have focused mostly on heterogeneous chemistry on East Asian and Saharan dust aerosols, whereas there have been no such studies over the northern Indian region where dust storms occur frequently during the pre-monsoon (March, April, May; MAM) season (e.g., Prasad and Singh, 2007; Hegde et al., 2007). Global modeling studies have suggested that heterogeneous chemistry on dust aerosols can reduce surface $\mathrm{O}_{3}$ in northern India by 4-10\% (e.g., Dentener et al., 1996; Bauer et al., 2004). However, there has been a considerable improvement in our understanding of heterogeneous chemistry on dust aerosols since these global modeling studies were conducted. A major advancement has been the demonstration of relative humidity (RH) dependence of the reactive uptake coefficient for several species such as $\mathrm{O}_{3}$ (Cwiertny et al., 2008), $\mathrm{HNO}_{3}$ (Liu et al., 2008), $\mathrm{OH}$ (Bedjanian et al., 2013a), $\mathrm{HO}_{2}$ (Bedjanian et al., 2013b), $\mathrm{SO}_{2}$ (Preszler Prince et al., 2007) and $\mathrm{H}_{2} \mathrm{O}_{2}$ (Pradhan et al., 2010). The renoxification process (Eq. 1), which was ignored in those global modeling studies, is also included here. In this process, the uptake of gas-phase $\mathrm{HNO}_{3}$ by dust particles is followed by release of gas-phase $\mathrm{NO}_{\mathrm{x}}$ (both $\mathrm{NO}$ and $\mathrm{NO}_{2}$ ) in the presence of broadband radiation (e.g., Chen et al., 2011).

$\mathrm{HNO}_{3}(\mathrm{~g})+$ Dust $\stackrel{\mathrm{NO}_{3}^{-}(\mathrm{p}), h v}{\longrightarrow} \mathrm{NO}_{\mathrm{x}}(\mathrm{g})$,

where $(\mathrm{g})$ and $(\mathrm{p})$ represent the species in gas and particle phase respectively. Therefore, it is essential to reassess the importance of dust aerosols for tropospheric chemistry in northern India by taking into account these recent advancements.

In light of the above conditions, this manuscript examines the effects of dust aerosols on the distribution of many key trace gases including $\mathrm{O}_{3}$, nitrogen oxides, hydrogen oxides, methanol, acetic acid and formaldehyde by incorporating the updated information on heterogeneous reactive uptake of trace gases in MOZCART chemical mechanism of Weather Research and Forecasting model coupled with Chemistry (WRF-Chem). We also revise the Fast Troposphere Ultraviolet Visible (F-TUV) scheme to include effects of dust aerosols on photolysis rates. This extended configuration of WRF-Chem is then used to simulate the impact of a typical pre-monsoon season dust storm on the regional tropospheric chemistry in northern India. This dust storm occurred during 17-22 April 2010 in northern India. A detailed analysis of the evolution of this dust storm, dust emissions and their effect on local to regional-scale aerosol optical properties and radiation budget is presented in a companion paper (Kumar et al., 2014).

We begin by describing the WRF-Chem configuration and implementation of effect of dust aerosols on photolysis rates and heterogeneous chemistry on dust surfaces. We next briefly describe the observations used to evaluate the WRFChem trace gas results. In the Results section, we show the importance of dust effects on tropospheric gas chemistry by comparing the model results with observations. Sensitivity simulations are used to discuss the contributions of different processes and evaluate the uncertainties in the representation of heterogeneous chemistry. We conclude that heterogeneous chemistry mostly, partly dust-modified photolysis rates, improves the agreement between model results and observations, and that these processes lead to a reduction in $\mathrm{O}_{3}$, $\mathrm{H}_{2} \mathrm{O}_{2}$, and $\mathrm{HNO}_{3}$. 


\section{The WRF-Chem model}

The Weather Research and Forecasting Model version 3.4.1 (Skamarock et al., 2008) coupled with Chemistry (Grell et al., 2005; Fast et al., 2006) is used here to simulate the distribution of trace species. The simulation domain has $120 \times 90 \times 51$ grid points in $(x, y, z)$ direction with a grid spacing of $30 \times 30 \mathrm{~km}^{2}$ extending in the vertical up to $10 \mathrm{hPa}$. The static geographical fields, such as terrain height, vegetation fraction, soil properties and land use, etc., are interpolated from $10 \mathrm{~min}(\sim 19 \mathrm{~km})$ United States Geological Survey (USGS) data to the model domain by using the WRF preprocessing system (WPS). The initial and lateral boundary conditions for the meteorological fields are obtained from the National Center for Environmental Predictions (NCEP) Final Analysis (FNL) fields available every $6 \mathrm{~h}$ at a spatial resolution of $1^{\circ} \times 1^{\circ}$. The resolved scale cloud physics is represented by the Thompson microphysics scheme (Thompson et al., 2004), and subgrid-scale effects of convective and shallow clouds are parameterized according to the KainFritsch convective scheme (Kain, 2004). The short- and longwave radiative processes in the atmosphere are represented by the Rapid Radiative Transfer Model (RRTM) (Mlawer et al., 1997). For surface processes, the model setup uses the NOAH Land Surface model (Chen and Dudhia, 2001) and MM5 similarity scheme (Beljaars, 1994). The vertical subgrid-scale fluxes due to eddy transport in the planetary boundary layer (PBL) and the free troposphere are parameterized according to the Yonsei University (YSU) boundary layer scheme (Hong et al., 2006). Four-dimensional data assimilation (FDDA) is applied to limit model errors in the simulated meteorological fields (Lo et al., 2008).

Gas-phase chemistry is represented by the Model for Ozone and Related chemical Tracers, version 4 (MOZART4, Emmons et al., 2010), and aerosol processes by the GOCART bulk aerosol scheme (Chin et al., 2002; Pfister et al., 2011). The GOCART model simulates five major tropospheric aerosol types including sulfate, organic carbon, black carbon, dust and sea salt, assuming externally mixed aerosols. The GOCART model does not have an aerosol thermodynamics module. The emissions of sea salt (four size bins) and dust aerosols (five size bins) are calculated online within the model. The dust emission scheme is based on Ginoux et al. (2001) and calculates size-resolved dust emissions online in five size bins ranging from 0.73 to $8.0 \mu \mathrm{m}$ (effective radius) using the following equation:

$F_{p}=\left\{\begin{array}{l}C S s_{p} u_{10 \mathrm{~m}}^{2}\left(u_{10 \mathrm{~m}}-u_{\mathrm{t}}\right) \text { if } u_{10 \mathrm{~m}}>u_{t} \\ 0 \text { otherwise }\end{array}\right.$,

where $F_{p}\left(\mathrm{~kg} \mathrm{~m}^{-2} \mathrm{~s}^{-1}\right)$ represents the emission flux for size bin $p, C$ is an empirical proportionality constant $\left(\mathrm{kg} \mathrm{m}^{-5} \mathrm{~s}^{2}\right)$, $S$ is the source function representing the fraction of alluvium available for wind erosion, $s_{p}$ is the fraction of each size class of dust in the emission, $u_{10 \mathrm{~m}}\left(\mathrm{~m} \mathrm{~s}^{-1}\right)$ is the horizontal wind speed at $10 \mathrm{~m}$ above the surface and $u_{\mathrm{t}}$ is the threshold velocity $\left(\mathrm{m} \mathrm{s}^{-1}\right)$ below which dust emission does not occur and is a function of particle size and density, air density and surface moisture. In principle, $S$ should be based on observations of alluvium in the model domain, but such observations do not exist. Therefore, $S$ is obtained by comparing elevation of each grid cell with its surrounding hydrological basin spread over an area of $10^{\circ} \times 10^{\circ}$. Thus, $S$ does not provide the exact amount of alluvium present, but it provides information about the most probable locations of sediments. The map of $S$ is then compared with vegetation map derived from Advanced Very High Resolution Radiometer (AVHRR) data (DeFries and Townshend, 1994), and only the bare soil surfaces are considered as possible dust sources. In WRF-Chem, the source function is provided as an input static geographical field through the WRF preprocessing system (WPS). The threshold wind velocity $u_{\mathrm{t}}$ is estimated as

$u_{\mathrm{t}}=\left\{\begin{array}{l}A \sqrt{\frac{\left(\rho_{\mathrm{p}}-\rho_{\mathrm{a})} g \Phi_{\mathrm{p}}\right.}{\rho_{\mathrm{a}}}} \\ \infty \text { otherwise }\end{array} \quad\left(1.2+0.2 \log _{10} w\right)\right.$, if $w<0.5$,

where $A=6.5$ is a dimensionless parameter, $w$ is the surface wetness $(0.001-1), \Phi_{\mathrm{p}}$ is the particle diameter, $g$ is the acceleration of gravity, and $\rho_{\mathrm{a}}$ and $\rho_{\mathrm{p}}$ are the air and particle density respectively. More information about estimation of $S$ and $u_{\mathrm{t}}$ can be obtained from Ginoux et al. (2001).

The tuning factor $C$ does not have any physical meaning. Its default value was proposed initially as $1 \times 10^{-9} \mathrm{~kg} \mathrm{~m}^{-5} \mathrm{~s}^{2}$ (Ginoux et al., 2001), but we have set it to $2.2 \times 10^{-8} \mathrm{~kg} \mathrm{~m}^{-5} \mathrm{~s}^{2}$ as the latter value led to a good agreement between model and Aerosol Robotic Network (AERONET) measured aerosol optical depth and Angström exponent at seven sites in the model domain (Kumar et al., 2014). A factor of magnitude difference in the value of $C$ results partly from the use of analysis nudging (FDDA) in this study as nudging leads to lower wind speeds. A sensitivity experiment showed that similar dust emissions could be obtained with a $C$ value of $9 \times 10^{-9} \mathrm{~kg} \mathrm{~m}^{-5} \mathrm{~s}^{2}$ without applying analysis nudging. However, we chose to use analysis nudging as the model configuration with analysis nudging is found to better reproduce the variations in observed aerosol optical properties as compared to one without analysis nudging (not shown).

Anthropogenic emissions of $\mathrm{CO}, \mathrm{NO}_{\mathrm{x}}, \mathrm{SO}_{2}, \mathrm{NH}_{3}$, OC and $\mathrm{BC}$ and non-methane volatile organic compounds (NMVOCs) are taken from the MACCity emission inventory (Granier et al., 2011) and emissions for $\mathrm{PM}_{2.5}$ and $\mathrm{PM}_{10}$ are taken from the Intercontinental Chemical Transport Experiment - Phase B (INTEX-B) inventory (Zhang et al., 2009). Daily varying emissions of trace species from biomass burning are taken from the Fire Inventory from NCAR version 1 (FINN v1) (Wiedinmyer et al., 2011) and distributed vertically in the model following the online plume-rise module (Freitas et al., 2007). Note that FINN v1 accounts only for 
open biomass burning, and the residential biomass burning is included in anthropogenic emissions. Biogenic emissions of trace species from terrestrial ecosystems are calculated online using the Model of Emissions of Gases and Aerosols from Nature (MEGAN) version 2.04 (Guenther et al., 2006). The aerosols are allowed to provide feedback to the radiation scheme in the simulations but through direct effects only. The simulations start on 10 April 2010 at 00:00 GMT and end on 25 April 2010 at 18:00 GMT. The first 3 days of the model output are removed from the analysis to allow the model to spin up.

\subsection{Effect of aerosols on photolysis rates in WRF-Chem}

In this study, we use the Fast-Troposphere Ultraviolet Visible (F-TUV) scheme to calculate photolysis rates for the MOZCART chemical mechanism. The F-TUV scheme is a simplified version of the National Center for Atmospheric Research's (NCAR) TUV model (Madronich and Weller, 1990) and is designed to reduce the computational costs associated with TUV (Tie et al., 2005). The F-TUV model utilizes the same physical processes as the TUV model except that the number of wavelengths in the TUV spectra $(121-750 \mathrm{~nm})$ was reduced from 140 to 17 , making it eight times faster than the TUV model. The differences in the calculated photolysis rate coefficients between the TUV and F-TUV model are reported to be less than $5 \%$ (Tie et al., 2005).

To include the effect of aerosols on photolysis rates, the F-TUV photolysis scheme in WRF-Chem calculates optical properties (optical depth, single scattering albedo and asymmetry parameter) for black carbon, organic carbon, sulfate and sea-salt aerosols, and passes them to a two-stream radiative transfer module where they interact with radiation to affect photolysis rate coefficients. These optical properties are also calculated in the aerosol optical driver of WRFChem and are used for feedback of aerosols on the meteorology radiation schemes. Here, we make use of the optical driver calculated aerosol optical properties in F-TUV photolysis scheme to be consistent between the effects of aerosols on radiation and photolysis rate coefficients. This coupling automatically accounts for the effect of dust aerosols on photolysis rates in WRF-Chem, which was missing in the original F-TUV scheme. Further details regarding the coupling of the optical driver to the F-TUV photolysis scheme can be found in the supplementary material.

\subsection{Heterogeneous chemistry on dust surface in WRF-Chem}

This study also extends the ability of the MOZCART chemical mechanism of WRF-Chem to simulate heterogeneous chemistry on the surface of dust particles by including 12 heterogeneous reactions listed in Table 1. The uptake of these gases on dust particles is assumed to be irreversible (Zhang and Carmichael, 1999) and does not add to the aerosol mass in the model because the GOCART model does not have a thermodynamics module. However, recent laboratory experiments have shown that the uptake of $\mathrm{HNO}_{3}$ (Chen et al., 2011 ) is associated with release of gas-phase $\mathrm{NO}_{\mathrm{x}}$, and uptake of $\mathrm{OH}$ (Bedjanian et al., 2013a) and $\mathrm{HO}_{2}$ (Bedjanian et al., 2013b) are associated with the release of gas-phase $\mathrm{H}_{2} \mathrm{O}_{2}$. The production of these gas-phase species from heterogeneous chemistry is taken into account in this study. The production of $\mathrm{NO}_{\mathrm{x}}$ from $\mathrm{HNO}_{3}$ uptake is observed only in the presence of broadband irradiation with a yield of about $50 \%$ (Chen et al., 2011), and thus the reaction of $\mathrm{HNO}_{3}$ is set to yield $0.5 \mathrm{NO}_{2}$ during daytime in this study. This yield of 0.5 results from the assumption that all $\mathrm{HNO}_{3}$ molecules reacting with dust particles adsorb to the surface, but $\mathrm{HNO}_{3}$ has been observed to be lost irreversibly when reacting with $\mathrm{CaCO}_{3}$ and adsorb to the surface when reacting with other minerals (e.g., $\mathrm{Al}_{2} \mathrm{O}_{3}, \mathrm{Fe}_{2} \mathrm{O}_{3}$, and $\mathrm{TiO}_{2}$ ) (Grassian, 2002). For Indian dust particles, the abundance of $\mathrm{CaCO}_{3}$ is estimated to be about $20 \%$ (Peterson, 1968). If we assume that $\mathrm{HNO}_{3}$ will react with the remaining $80 \%$ of the minerals adsorbing to the surface, the yield should be 0.4 . However, our assumption of a yield of 0.5 should not affect the model results significantly here as it is shown later (Sect. 4.3) that the renoxification process leads only to a small change in $\mathrm{NO}_{\mathrm{x}}$ values. The yields for $\mathrm{H}_{2} \mathrm{O}_{2}$ from reactions of $\mathrm{OH}$ and $\mathrm{HO}_{2}$ with dust particles are reported to be $5 \%$ (Bedjanian et al., 2013a) and 10\% (Bedjanian et al., 2013b) respectively and are set accordingly. These numbers differ from previous studies, which have assumed a $100 \%$ conversion of $\mathrm{HO}_{2}$ and $0 \%$ conversion of $\mathrm{OH}$ into $\mathrm{H}_{2} \mathrm{O}_{2}$ (e.g., Zhu et al., 2010; Wang et al., 2012).

The pseudo-first-order reaction rate coefficient $\left(\mathrm{s}^{-1}\right)$ for the loss of a gas-phase species $g$ due to heterogeneous uptake by dust particles is calculated following Heikes and Thompson (1983) as

$k_{\mathrm{g}}=\sum_{i=1}^{5} \frac{4 \pi r_{i} D_{\mathrm{g}} V N_{i}}{1+K n[\chi+4(1-\gamma) / 3 \gamma]}$,

where $i=1,5$ represents five dust size bins used by the GOCART model, $r_{i}$ and $N_{i}$ represents the effective radius $(\mathrm{cm})$ and number density (particles $\mathrm{cm}^{-3}$ ) of particles in size bin $i, V$ is the ventilation coefficient and taken as unity, and $D_{\mathrm{g}}$ represents the gas-phase molecular diffusion coefficient of gas molecule $g\left(\mathrm{~cm}^{2} \mathrm{~s}^{-1}\right)$ and is calculated following Jacobson (2005) as

$D_{\mathrm{g}}=\frac{5}{16 \rho_{\mathrm{a}} A d_{\mathrm{g}}^{2}} \sqrt{\left(\frac{m_{\mathrm{a}}+m_{\mathrm{g}}}{m_{\mathrm{g}}}\right) \frac{R T m_{\mathrm{a}}}{2 \pi}}$,

where $\rho_{\mathrm{a}}$ is atmospheric mass density $\left(\mathrm{g} \mathrm{cm}^{-3}\right), A$ is the Avogadro number $\left(6.022 \times 10^{23}\right.$ molecules $\left.\mathrm{mol}^{-1}\right), d_{\mathrm{g}}$ is the collision diameter $(\mathrm{cm})$ of gas molecule $g, R$ is the universal gas constant $\left(8.31451 \times 10^{7} \mathrm{~g} \mathrm{~cm}^{2} \mathrm{~s}^{-2} \mathrm{~mol}^{-1} \mathrm{~K}^{-1}\right), T$ is the absolute temperature $(\mathrm{K})$, and $m_{\mathrm{a}}\left(\mathrm{g} \mathrm{mol}^{-1}\right)$ and $m_{\mathrm{g}}\left(\mathrm{g} \mathrm{mol}^{-1}\right)$ 
Table 1. The heterogeneous reactions and dry reactive uptake coefficients $\left(\gamma_{\text {dry }}\right)$ used in this study are listed. $\gamma_{\text {low }}$ and $\gamma_{\text {high }}$ represent lower and upper bounds of reactive uptake coefficient reported in the literature. The rightmost column shows the references based on which relative humidity dependence of $\gamma_{\text {dry }}$ is specified.

\begin{tabular}{lcccl}
\hline Reaction & $\gamma_{\text {low }}$ & $\gamma_{\text {dry }}$ & $\gamma_{\text {high }}$ & RH dependence \\
\hline $\mathrm{O}_{3}+$ Dust $\rightarrow$ P & $1 \times 10^{-6}$ & $2.7 \times 10^{-5}$ & $1 \times 10^{-4}$ & Cwiertny et al. (2008) \\
$\mathrm{HNO}_{3}+$ Dust $\rightarrow$ 0.5 $\mathrm{NO}_{\mathrm{x}}+\mathrm{P}$ & $1 \times 10^{-5}$ & $2.0 \times 10^{-3}$ & 0.2 & Liu et al. (2008) \\
$\mathrm{NO}_{2}+$ Dust $\rightarrow \mathrm{P}$ & $4 \times 10^{-10}$ & $2.1 \times 10^{-6}$ & $2 \times 10^{-4}$ & - \\
$\mathrm{NO}_{3}+$ Dust $\rightarrow \mathrm{P}$ & 0.01 & 0.1 & 0.23 & - \\
$\mathrm{N}_{2} \mathrm{O}_{5}+$ Dust $\rightarrow \mathrm{P}$ & 0.01 & 0.03 & 0.1 & - \\
$\mathrm{OH}+$ Dust $\rightarrow$ 0.05 $\mathrm{H}_{2} \mathrm{O}_{2}+\mathrm{P}$ & 0.004 & 0.18 & 1 & Bedjanian et al. (2013a) \\
$\mathrm{HO}_{2}+$ Dust $\rightarrow$ 0.1 $\mathrm{H}_{2} \mathrm{O}_{2}+\mathrm{P}$ & 0.01 & $6.4 \times 10^{-2}$ & 1 & Bedjanian et al. (2013b) \\
$\mathrm{H}_{2} \mathrm{O}_{2}+$ Dust $\rightarrow \mathrm{P}$ & $8 \times 10^{-4}$ & $2 \times 10^{-3}$ & 0.18 & Pradhan et al. (2010) \\
$\mathrm{SO}_{2}+$ Dust $\rightarrow \mathrm{P}$ & $5 \times 10^{-7}$ & $3.0 \times 10^{-5}$ & $2.6 \times 10^{-4}$ & Preszler Prince et al. (2007) \\
$\mathrm{CH}_{3} \mathrm{COOH}+\mathrm{Dust} \rightarrow \mathrm{P}$ & $2.4 \times 10^{-4}$ & $1 \times 10^{-3}$ & $2 \times 10^{-3}$ & - \\
$\mathrm{CH}_{3} \mathrm{OH}+\mathrm{Dust} \rightarrow \mathrm{P}$ & $4 \times 10^{-6}$ & $1 \times 10^{-5}$ & $1.9 \times 10^{-4}$ & - \\
$\mathrm{CH}_{2} \mathrm{O}+\mathrm{Dust} \rightarrow \mathrm{P}$ & $2.6 \times 10^{-7}$ & $1 \times 10^{-5}$ & $1.1 \times 10^{-4}$ & - \\
\hline
\end{tabular}

are the molecular weights of air and gas respectively. In Eq. (3), $K n$ is the dimensionless Knudsen number defined as the ratio of the effective mean free path of a gas molecule in air $(\lambda)$ to the effective particle radius $r_{i} . \chi$ represents a correction factor for anisotropic movement and is calculated as follows:

$\chi=\frac{\left(\frac{4}{3} K n+0.71\right)}{K n+1}$

WRF-Chem model simulates the mass mixing ratio $\left(M_{i}\right.$ in $\mathrm{g} \mathrm{g}^{-1}$ ) of dust particles, and the use of Eq. (3) requires the conversion of mass mixing ratios to the number concentration. This is performed using the following equation:

$N_{i}=\frac{M_{i} \rho_{\mathrm{a}}}{\left(\frac{4}{3} \pi r_{i}^{3}\right) \rho_{\mathrm{p}}}$

where $\rho_{\mathrm{p}}\left(\mathrm{g} \mathrm{cm}^{-3}\right)$ represents the mass density of the dust particles, which are taken as 2.5 and $2.65 \mathrm{~g} \mathrm{~cm}^{-3}$ to represent clay and silt in GOCART (Ginoux et al., 2001).

The reaction uptake coefficient $(\gamma)$ is the most important parameter in the calculation of $k_{\mathrm{g}}$, but the uncertainties in $\gamma$ are very large and have been reported as more than 3 orders of magnitudes for certain species such as $\mathrm{O}_{3}$ and $\mathrm{HNO}_{3}$ (Goodman et al., 2000; Underwood et al., 2001; Michel et al., 2002). Such large uncertainties make the choice of $\gamma$ very difficult. Since this study is focusing on Thar Desert dust aerosols for which information on heterogeneous chemistry kinetics is not available, we use the best guess values reported for East Asian dust aerosols (Zhu et al., 2010) for the $\gamma$ values of dry dust particles except for $\mathrm{OH}$ and $\mathrm{HO}_{2}$. The $\gamma$ values for $\mathrm{OH}$ and $\mathrm{HO}_{2}$ are taken from Bedjanian et al. $(2013 \mathrm{a}, \mathrm{b})$. The applied $\gamma$ values for dry dust particles are shown in Table 1 and vary from $2.1 \times 10^{-6}$ for $\mathrm{NO}_{2}$ to 0.18 for $\mathrm{OH}$. Lower and upper bounds of $\gamma$ reported in the literature are also shown in Table 1. Further information about available measurements of $\gamma$ for different species can be found in Zhu et al. (2010).

Many laboratory studies have also demonstrated the dependence of $\gamma$ on relative humidity $(\mathrm{RH})$, but such a $\mathrm{RH}$ dependence has generally been ignored in previous modeling studies (e.g., Dentener et al., 1996; Zhu et al., 2010; Wang et al., 2012). In this study, we include the RH dependence of $\gamma$ for $\mathrm{O}_{3}$ (Cwiertny et al., 2008), $\mathrm{HNO}_{3}$ (Liu et al., 2008), $\mathrm{OH}$ (Bedjanian et al., 2013a), $\mathrm{HO}_{2}$ (Bedjanian et al., 2013b), $\mathrm{H}_{2} \mathrm{O}_{2}$ (Pradhan et al., 2010), and $\mathrm{SO}_{2}$ (Preszler Prince et al., 2007). The variations of $\gamma$ with relative humidity for different trace gases are shown in Fig. 1. The value of $\gamma$ increases with $\mathrm{RH}$ for $\mathrm{HNO}_{3}, \mathrm{SO}_{2}$ and $\mathrm{H}_{2} \mathrm{O}_{2}$ while it decreases with $\mathrm{RH}$ for $\mathrm{O}_{3}, \mathrm{OH}$ and $\mathrm{HO}_{2}$. The rate coefficients, i.e., $k_{\mathrm{g}}$ values, are estimated to be of the order of $10^{-3}-10^{-5} \mathrm{~s}^{-1}$ for $\mathrm{OH}, \mathrm{HO}_{2}, \mathrm{H}_{2} \mathrm{O}_{2}, \mathrm{HNO}_{3}, \mathrm{NO}_{3}, \mathrm{~N}_{2} \mathrm{O}_{5}$ and $\mathrm{CH}_{3} \mathrm{COOH}$, and of the order of $10^{-7}-10^{-8} \mathrm{~s}^{-1}$ for $\mathrm{O}_{3}, \mathrm{NO}_{2}, \mathrm{SO}_{2}, \mathrm{CH}_{3} \mathrm{OH}$ and $\mathrm{CH}_{2} \mathrm{O}$.

The aging of dust particles through heterogeneous uptake of acidic gases and organic compounds is another important process that can influence the uptake of trace gases by dust particles. However, the dependence of $k_{\mathrm{g}}$ on aging of mineral dust aerosols is complex and not well understood. For example, the reactive uptake of $\mathrm{O}_{3}$ (Usher et al., 2003) on $\mathrm{HNO}_{3}$ and $\mathrm{SO}_{2}$ processed dust particles is reported to increase or decrease depending on the mineralogy of the particle, coverage of the coatings, as well as ambient RH. Due to the complexity of processes involved and lack of information on all 12 heterogeneous reactions, the effect of atmospheric processing of dust particles is not included in this study except for a set of sensitivity simulations conducted to highlight the importance of this aging process. The treatment of dust aging for those sensitivity simulations is presented below. 


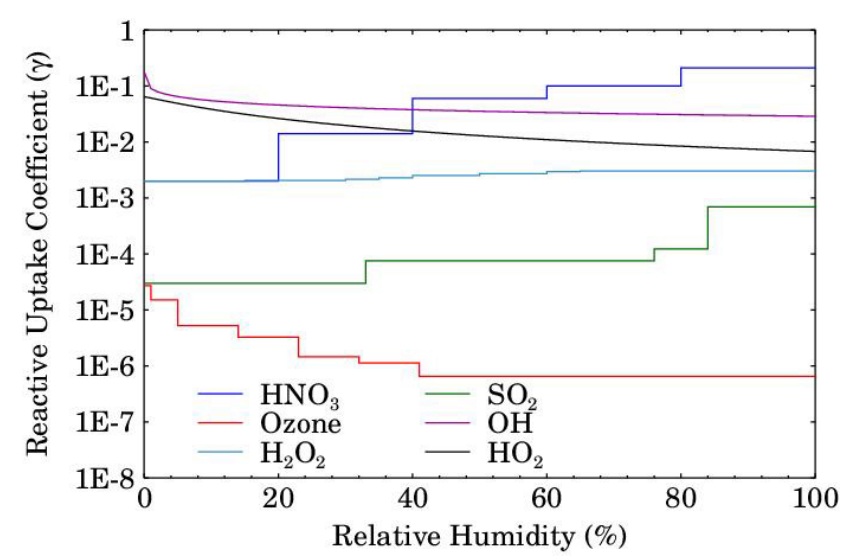

Figure 1. The relative humidity dependence of reactive uptake coefficient $(\gamma)$ for $\mathrm{O}_{3}, \mathrm{HNO}_{3}, \mathrm{OH}, \mathrm{HO}_{2}, \mathrm{H}_{2} \mathrm{O}_{2}$ and $\mathrm{SO}_{2}$ used in this study.

\subsection{Atmospheric aging/processing of dust particles}

Laboratory experiments have shown that reactive uptake of $\mathrm{O}_{3}$ decreases by about $70 \%$ on dust particles processed with $\mathrm{HNO}_{3}$ (leading to nitrate coating) while it increases by about $33 \%$ on dust particles processed with $\mathrm{SO}_{2}$ as $\mathrm{O}_{3}$ reacts with surface-bound sulfites/bisulfites to form sulfate (Usher et al., 2003). We have made an attempt here to simulate these changes in dust reactivity and quantify their impact on surface $\mathrm{O}_{3}$. The simulation of these changes requires partitioning of fresh and aged dust particles and is done using the following procedure: in addition to total dust, two artificial dust tracers called "fresh_dust" and "aged_dust" are introduced into the model to keep track of fresh and aged dust particles. These tracers are included for all five size bins, and thus we have a total of 10 tracers in the model. All these tracers undergo the same transport and deposition processes as the original dust tracers.

The emissions of fresh dust particles are set equal to the emissions of total dust while the emissions of aged dust particles are set to zero. The initial and boundary conditions for fresh dust particles are set equal to those for total dust while those for aged dust particles are set to zero because the MOZART-4 output used for providing initial and boundary conditions does not include such a classification. The assumption that all dust particles entering into the model domain are fresh may introduce some uncertainty in the model results. However, such an uncertainty is anticipated to have a small contribution in the case presented here, as two model runs with and without including the regional dust emissions showed that most of the dust loading over the model domain came from emissions within the model domain during 17-22 April 2010.

The number concentration (particles $\left.\mathrm{cm}^{-3}\right)$ of aged $\left(N_{\mathrm{a}, i}\right.$, $i=1,5$ represent five size bins) and fresh $\left(N_{\mathrm{f}, i}\right)$ dust particles is updated every time step as follows for each gas $g$ considered: first, the number of molecules of gas $g$ needed to completely coat one dust particle of a given size with a monolayer $\left(n_{\mathrm{ml}, \mathrm{g}, i}\right)$ is calculated as the ratio of surface area of the dust particle to the surface area occupied by a gas molecule. Second, the total number of gas molecules of $g$ that can potentially adsorb to dust particles $\left(n_{\mathrm{pot}, \mathrm{g}, i}\right)$ is calculated by multiplying $k_{\mathrm{g}}\left(\mathrm{s}^{-1}\right)$ estimated in Eq. (3) with gas concentration (molecules $\mathrm{cm}^{-3}$ ) and time step (180 s in this case). The ratio $n_{\mathrm{pot}, \mathrm{g}, i} / n_{\mathrm{ml}, \mathrm{g}, i}$ then provides the number concentration increment $\Delta N_{\mathrm{a}, \mathrm{g}, i}$ of dust particles that could have aged (i.e., been completely coated with a monolayer of gas) during this time step. The sum of the increments $\Delta N_{\mathrm{a}, \mathrm{g}, i}$ due to all gases considered in coating gives the total increment in aged particles $\Delta N_{\mathrm{a}, i} . \Delta N_{\mathrm{a}, i}$ is then subtracted from the number concentration of fresh dust particles $N_{\mathrm{f}, i}$ and added accordingly to the number concentration of aged particles $N_{\mathrm{a}, i}$.

The reactions of $\mathrm{HNO}_{3}, \mathrm{NO}_{2}, \mathrm{NO}_{3}$ and $\mathrm{N}_{2} \mathrm{O}_{5}$ with dust particles are assumed to coat dust particles with nitrate and that of $\mathrm{SO}_{2}$ is assumed to coat them with sulfate. All gases are given equal probability to react with dust particles, and in case the number concentration of fresh dust particles is limiting, then $\Delta N_{\mathrm{a}, i}>N_{\mathrm{f}, i}$, which would lead to negative number concentrations of $N_{\mathrm{f}, i}$. To overcome this problem, $N_{\mathrm{a}, i}$ and $N_{\mathrm{f}, i}$ are set to $N_{\mathrm{f}, i}$ and zero respectively. This approach leads to mass conservation of tracers, and the sum of fresh and aged dust particle concentrations is always equal to the total dust number concentration. Both fresh and coated dust particles then react separately with trace gases.

\subsection{Simulations conducted}

Eleven simulations were conducted (Table 2) to examine the impact of the dust storm on tropospheric chemistry. No_Dust serves as a base simulation in which heterogeneous chemistry on dust surfaces and the effect of dust on photolysis rates are not included. Dust_J simulation includes the effect of dust aerosols on photolysis rates, while Dust_JH simulation is same as Dust_J but with addition of heterogeneous chemistry on dust surface taking into account the RH dependence of $\gamma$ and renoxification process. Dust_JH_NoRH simulation is same as Dust_JH except that it does not include the RH dependence of $\gamma$. In Dust_JH_NoReNO ${ }_{x}$, the release of gas-phase $\mathrm{NO}_{2}$ associated with uptake of $\mathrm{HNO}_{3}$ is excluded in order to assess the importance of the renoxification process. Dust_JH_LoG and Dust_JH_HiG simulations are conducted with lower and upper bounds of $\gamma$ reported in the literature in order to provide an estimate of the uncertainty in heterogeneous chemistry induced changes in tropospheric chemistry due to the uncertainty in $\gamma$. Dust_JH_ $\mathrm{NO}_{3}$ and Dust_JH_SO 4 simulations are designed to examine the influences of dust coated with nitrate and sulfate separately on the uptake of $\mathrm{O}_{3}$. In these simulations, the uptake coefficient $\gamma$ for aged dust particles is reduced by $70 \%$ in Dust_JH_NO $\mathrm{NO}_{3}$ and is increased by $33 \%$ in Dust_JH_SO $\mathrm{JH}_{4}$ (Usher et al., 2003). Dust particles are coated with both sulfate and nitrate 
in Dust_JH_NO $\mathrm{NO}_{3} \mathrm{SO}_{4}$ to examine the combined effect of nitrate and sulfate coating on $\mathrm{O}_{3}$ uptake. In this simulation, three reactions of $\mathrm{O}_{3}$ are included: with fresh dust particles, dust particles coated with nitrate and dust particles coated with sulfate. The original $\gamma$ value is used for reaction with fresh dust particles, while the original $\gamma$ value is reduced by $70 \%$ for reaction with dust particles coated with nitrate and is increased by $33 \%$ for reaction with dust particles coated with sulfate. Dust_JH_Sat is a hypothetical simulation where we assume that the presence of a nitrate or sulfate monolayer on the dust particle would saturate the dust particles and deactivate them for further catalytic uptake of $\mathrm{O}_{3}, \mathrm{OH}, \mathrm{HO}_{2}$, $\mathrm{H}_{2} \mathrm{O}_{2}, \mathrm{CH}_{3} \mathrm{COOH}, \mathrm{CH}_{3} \mathrm{OH}$ and $\mathrm{HCHO}$, but the coating is assumed to have no effect on the uptake of $\mathrm{HNO}_{3}, \mathrm{NO}_{2}$, $\mathrm{NO}_{3}, \mathrm{~N}_{2} \mathrm{O}_{5}$ and $\mathrm{SO}_{2}$. This comparison of Dust_JH_Sat with Dust_JH and Dust_J would provide bounds of the heterogeneous chemistry induced changes in tropospheric chemistry.

\section{Observation data sets}

\subsection{Surface observations}

This study uses surface $\mathrm{O}_{3}$ and $\mathrm{NO}_{\mathrm{y}}$ (sum of nitrogen oxides) observations made at the high-altitude site Nainital ( $79.45^{\circ} \mathrm{E}, 29.36^{\circ} \mathrm{N}, 1958 \mathrm{~m}$ a.m.s.l.) located in the central Himalayas. The observation site is bounded by high- altitude $(2-5 \mathrm{~km})$ mountains in the north and east directions and opens to the Indo-Gangetic Plain region in the south and west directions. There are no major anthropogenic sources near Nainital, and thus the observations at this site are envisaged to be representative of northern India (Kumar et al., 2010). Further details regarding the orography, vegetation cover, meteorological and chemical characteristics of Nainital can be found elsewhere (e.g., Sagar et al., 2004; Pant et al., 2006; Kumar et al., 2010; Sarangi et al., 2014). Ozone measurements are made using a standard ultraviolet absorption based instrument, and $\mathrm{NO}_{\mathrm{y}}$ measurements are made with a chemiluminescence-based instrument. More details about the measurement setup, operating principle, accuracy, detection limits and calibration procedure are discussed elsewhere (e.g., Kumar et al., 2010; Sarangi et al., 2014). The model results are also compared with Aerosol Robotic Network (AERONET) measurements at seven sites in the model domain. Further details of AERONET and these observations sites can be found in Kumar et al. (2014).

\subsection{Ozone Monitoring Instrument (OMI)}

The Ozone Monitoring Instrument (OMI), aboard NASA's Earth Observing System (EOS) Aura satellite, measures the radiation backscattered by the earth's atmosphere and surface over the $0.27-0.5 \mu \mathrm{m}$ wavelength range with a spatial resolution of about $13 \mathrm{~km} \times 24 \mathrm{~km}$ at nadir in normal operational mode. These measured radiances are used for daily global retrievals of several trace species, such as $\mathrm{O}_{3}, \mathrm{NO}_{2}$,
$\mathrm{BrO}, \mathrm{SO}_{2}, \mathrm{CH}_{2} \mathrm{O}$ and aerosols. However, we do not use OMI $\mathrm{O}_{3}$ and $\mathrm{SO}_{2}$ retrievals because of their low sensitivity in the lower troposphere, which is the region of interest in this study. We find that $\mathrm{OMI} \mathrm{SO}_{2}$ retrievals are very noisy as average OMI-retrieved $\mathrm{SO}_{2}$ planetary boundary layer (PBL) column amount values $(0.5-1.0 \mathrm{DU})$ are smaller than the reported standard deviation of the noise (1.5 DU). Here, we use Level-2 tropospheric column $\mathrm{NO}_{2}$ data sets made available by KNMI (Royal Netherlands Meteorological Institute) as they provide access to the averaging kernel and a priori profiles, which are needed to make a proper comparison between model profiles and satellite retrievals (e.g., Emmons et al., 2004). More details on the algorithm used to retrieve the tropospheric column $\mathrm{NO}_{2}$ abundances at KNMI are described by Bucsela et al. (2006). These OMI $\mathrm{NO}_{2}$ retrievals were found to correlate well with aircraft measurements made during the INTEX-B campaign (Boersma et al., 2008) and MAX-DOAS ground-based measurements (Kramer et al., 2008) but are also suggested to be biased positively by about 0-30\%, irrespective of season (e.g., Boersma et al., 2009a; Zhou et al., 2009).

To compare WRF-Chem results with OMI, the best quality OMI retrievals are used by reducing influence of clouds on OMI retrievals through selection of pixels with cloud fraction less than 0.3 and removing unreliable retrievals associated with a tropospheric column flag of greater than 0 (Boersma et al., 2009b). The nighttime pixels from OMI are also excluded for the comparison. These best quality retrievals are co-located in space and time with model output. The colocated WRF-Chem profiles are then transformed using the averaging kernel and a priori profiles used in the satellite retrievals to obtain a model profile that OMI would measure for the modeled state of the atmosphere in the absence of other errors. More details about the method of model-OMI data co-location and convolution of model profiles with averaging kernel and a priori files can be found in Kumar et al. (2012).

\section{Results and discussion}

\subsection{Model evaluation}

Dust storms in northern India are characterized by large increase in aerosol optical depth (AOD) (>50\%) and decrease in $\alpha(>70 \%)$ (Dey et al., 2004; Prasad and Singh, 2007). Both of these features were observed during this dust storm indicating that this was a typical pre-monsoon season dust storm (see Kumar et al., 2014) and can be considered as representative of dust storms in northern India. Kumar et al. (2014) also present a detailed evaluation of simulated aerosol optical properties, and here we present a summary. The simulated AOD, Angström exponent and single scattering albedo are compared against Aerosol Robotic Network (AERONET) measurements at seven sites in the 
Table 2. Simulation designs used in this study and their purpose are shown.

\begin{tabular}{|c|c|c|}
\hline Simulation index & Model configuration & Purpose \\
\hline No_Dust & $\begin{array}{l}\text { WRF-Chem without dust emis- } \\
\text { sions but other aerosols affects } \\
\text { photolysis rates }\end{array}$ & Serves as a base simulation \\
\hline Dust_J & $\begin{array}{l}\text { WRF-Chem with dust emis- } \\
\text { sions and all aerosols affects } \\
\text { photolysis rates }\end{array}$ & $\begin{array}{l}\text { Comparison with No_Dust will quan- } \\
\text { tify the effect of dust on photolysis rates } \\
\text { and tropospheric chemistry }\end{array}$ \\
\hline Dust_JH & $\begin{array}{l}\text { Same as Dust_J but with het- } \\
\text { erogeneous chemistry consider- } \\
\text { ing RH dependence of } \gamma \text { and } \\
\text { renoxification process included }\end{array}$ & $\begin{array}{l}\text { Comparison with No_Dust will yield } \\
\text { total impact of dust on tropospheric } \\
\text { chemistry, and comparison with } \\
\text { DUST_J will yield contribution of } \\
\text { heterogeneous chemistry }\end{array}$ \\
\hline Dust_JH_NoRH & $\begin{array}{l}\text { Same as Dust_JH but RH de- } \\
\text { pendence of } \gamma \text { is not included }\end{array}$ & $\begin{array}{l}\text { Comparison with Dust_JH will provide } \\
\text { information on RH dependence of het- } \\
\text { erogeneous uptake of gases by dust }\end{array}$ \\
\hline Dust_JH_NoReNO ${ }_{\mathrm{x}}$ & $\begin{array}{l}\text { Same as Dust_JH but renoxifi- } \\
\text { cation process is not included }\end{array}$ & $\begin{array}{l}\text { Comparison with Dust_JH will provide } \\
\text { contribution of renoxification process in } \\
\mathrm{NO}_{\mathrm{x}} \text { budget. }\end{array}$ \\
\hline Dust_JH_LoG & $\begin{array}{l}\text { Same as Dust_JH but with } \\
\text { lower limit of } \gamma\end{array}$ & \multirow{2}{*}{$\begin{array}{l}\text { Comparison with Dust_JH_HiG pro- } \\
\text { vides uncertainty in the effects of } \\
\text { heterogeneous chemistry due to uncer- } \\
\text { tainty in } \gamma\end{array}$} \\
\hline Dust_JH_HiG & $\begin{array}{l}\text { Same as Dust_JH but with up- } \\
\text { per limit of } \gamma\end{array}$ & \\
\hline Dust_JH_NO ${ }_{3}$ & $\begin{array}{l}\text { Same as Dust_JH but the effect } \\
\text { of nitrate-coated dust on uptake } \\
\text { of } \mathrm{O}_{3} \text { is included }\end{array}$ & $\begin{array}{l}\text { Comparison with Dust_JH will provide } \\
\text { information on changes in } \mathrm{O}_{3} \text { uptake } \\
\text { due to coating of dust with nitrate }\end{array}$ \\
\hline Dust_JH_SO 4 & $\begin{array}{l}\text { Same as Dust_JH but the effect } \\
\text { of sulfate-coated dust on uptake } \\
\text { of } \mathrm{O}_{3} \text { is included }\end{array}$ & $\begin{array}{l}\text { Comparison with Dust_JH will provide } \\
\text { information on changes in } \mathrm{O}_{3} \text { uptake } \\
\text { due to coating of dust with sulfate }\end{array}$ \\
\hline Dust_JH_NO $3 \_S_{4}$ & $\begin{array}{l}\text { Same as Dust_JH but the effect } \\
\text { of nitrate- and sulfate-coated } \\
\text { dust on uptake of } \mathrm{O}_{3} \text { is included }\end{array}$ & $\begin{array}{l}\text { Comparison with Dust_JH will provide } \\
\text { information on changes in } \mathrm{O}_{3} \text { uptake } \\
\text { due to coating of dust with nitrate and } \\
\text { sulfate }\end{array}$ \\
\hline Dust_JH_Sat & $\begin{array}{l}\text { Same as Dust_JH but nitrate- } \\
\text { and sulfate-coated particles are } \\
\text { assumed to be saturated }\end{array}$ & $\begin{array}{l}\text { Comparison with Dust_JH will provide } \\
\text { upper limit on the effect of dust aging } \\
\text { on the tropospheric chemistry }\end{array}$ \\
\hline
\end{tabular}

model domain. It is found that the model generally underestimates the AOD over the model domain but is able to capture the temporal variations $(r=0.5-0.88)$ seen in AERONET measurements. The good agreement between modeled and AERONET observed Angström exponent indicates that the model is able to capture dust-storm-induced variations in aerosol size. The comparison of model results with Moderate Resolution Imaging Spectroradiometer (MODIS) AOD retrievals shows that the model is also able to capture the spatial pattern of dust-storm-induced changes in the MODIS AOD as well as the spatial pattern of the dust plume. The average MODIS and WRF-Chem AOD (550 nm) values in the high dust-laden region are estimated as $0.80 \pm 0.30$ and $0.68 \pm 0.28$ respectively.

The variations in observed and WRF-Chem-simulated (No_Dust, Dust_J, Dust_JH_NoRH and DUST_JH) daily average $\mathrm{O}_{3}$ and $\mathrm{NO}_{y}$ at Nainital during 13-24 April 2010 are shown in Fig. 2. The modeled time series of relative humidity and dust mass concentration for particles of $0.73,1.4$ and $8.0 \mu \mathrm{m}$ effective radii at Nainital are also shown. Note that the WRF-Chem model at the resolution $\left(30 \times 30 \mathrm{~km}^{2}\right)$ used here is not able to capture the rapidly varying topography around Nainital, and the altitude of the site in the model is off by about $900 \mathrm{~m}$. To minimize the comparison errors induced by this spatial mismatch, we first obtain the altitude 


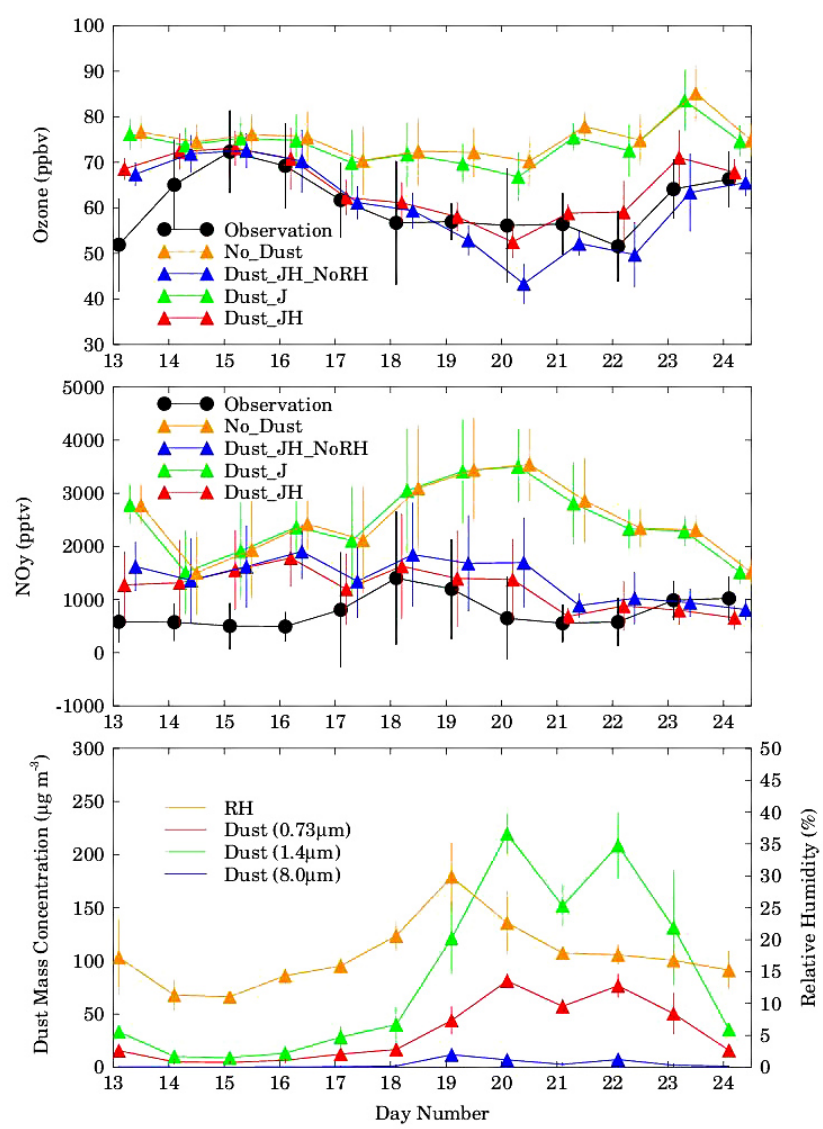

Figure 2. Variations in observed and WRF-Chem-simulated (No_Dust, Dust_JH_NoRH, Dust_J and Dust_JH) daily average $\mathrm{O}_{3}$ (top panel) and $\mathrm{NO}_{\mathrm{y}}$ (middle panel) at Nainital during 13-24 April 2010. WRF-Chem-simulated daily average mass concentration of dust particles of $0.73,1.4$ and $8.0 \mu \mathrm{m}$ effective radii and relative humidity at Nainital are also shown. The vertical bars represent standard deviation in the average values.

profile of model results at Nainital by bi-linearly interpolating model output at each model level to the location of Nainital $\left(79.45^{\circ} \mathrm{E}, 29.36^{\circ} \mathrm{N}\right)$ and then linearly interpolate the resulting altitude profile to the height of Nainital $(1958 \mathrm{~m})$. Dust mass concentrations started increasing at Nainital on 17 April 2010, reached a maximum during 20-22 April and decreased thereafter. The mass concentrations of $8.0 \mu \mathrm{m}$ particles remain close to zero even during the dust storm because these particles do not travel far from the source regions due to their higher deposition velocities resulting in dry deposition.

The observed $\mathrm{O}_{3}$ mixing ratios show a decrease during the dust storm period (17-22 April 2010), while observed $\mathrm{NO}_{\mathrm{y}}$ mixing ratios show an increase during 17-18 April 2010 and a decrease thereafter. Analysis of back-air trajectories arriving at Nainital (not shown) showed that the increase in $\mathrm{NO}_{\mathrm{y}}$ levels at Nainital during 17-18 April was associated with passage of low-altitude air masses over the Indo-Gangetic Plain region before arriving at Nainital, while air masses on previous days (15-16 April) passed over relatively cleaner regions to the north and west at higher altitudes. The WRF-Chem model without incorporating the effects of dust aerosols (No_Dust) does not capture the observed decrease in $\mathrm{O}_{3}$ and $\mathrm{NO}_{y}$ levels at Nainital. Including effects of dust on photolysis rates (Dust_J) induces a slight decrease (about $2 \mathrm{ppbv}$ ) in modeled $\mathrm{O}_{3}$ levels, but modeled values are still significantly higher than the observations. The introduction of heterogeneous chemistry without including RH dependence of $\gamma$ (Dust_JH_NoRH) in the model leads to the observed decreases in $\mathrm{O}_{3}$ and $\mathrm{NO}_{\mathrm{y}}$, but compared to measurements we find too strong of decreases in $\mathrm{O}_{3}$ levels and slightly higher $\mathrm{NO}_{\mathrm{y}}$ levels than the observations at Nainital during the peak of dust storm, i.e., 20-22 April 2010. The inclusion of heterogeneous chemistry with RH dependence of $\gamma$ (Dust_JH) leads to the best agreement between WRF-Chem-simulated and observed $\mathrm{O}_{3}$ and $\mathrm{NO}_{\mathrm{y}}$ values at Nainital. The WRF-Chem-simulated average $\mathrm{O}_{3}$ values at Nainital in Dust_JH and No_Dust configurations during 17-22 April 2010 are estimated to be $58 \pm 5 \mathrm{ppbv}$ and $73 \pm 6 \mathrm{ppbv}$ respectively as compared to the average observed value of $56 \pm 10 \mathrm{ppbv}$. The corresponding WRF-Chem $\mathrm{NO}_{\mathrm{y}}$ average values at Nainital are estimated as $1189 \pm 751 \mathrm{pptv}$ and $2945 \pm 876 \mathrm{pptv}$, respectively, as compared to the average observed value of $843 \pm 887 \mathrm{pptv}$. Thus, including the effects of dust aerosols in WRF-Chem reduces the difference between average modeled and observed $\mathrm{O}_{3}$ from $16 \pm 9$ to $2 \pm 8$ ppbv and that in $\mathrm{NO}_{\mathrm{y}}$ from $2102 \pm 1425$ to $346 \pm 1225$ pptv respectively.

The spatial distributions of average OMI-retrieved and WRF-Chem-simulated (Dust_JH and No_Dust) tropospheric column $\mathrm{NO}_{2}$ during 13-16 April 2010 and 17-22 April 2010 are shown in Fig. 3. The percentage differences in tropospheric column $\mathrm{NO}_{2}$ between high and low dust emission periods are also shown for both OMI and WRF-Chem. Both the model and satellite data show similar spatial distributions with the highest values along the Indo-Gangetic Plain region during both low and high dust emission periods, but WRF-Chem generally overestimates the OMI retrievals which is consistent with previous studies over the Indian region (Kumar et al., 2012; Ghude et al., 2013). However, the comparison between Dust_JH and No_Dust configurations of WRF-Chem shows that the inclusion of effects of dust aerosols improves the model performance and reduces the model bias with respect to OMI retrievals by up to $30 \%$ especially in the Indo-Gangetic Plain region. The remaining bias in the model could be due to uncertainties in $\mathrm{NO}_{\mathrm{x}}$ emission estimates in this region. The percentage difference plots show that the WRF-Chem model is able to capture several features of changes in OMI-retrieved spatial distribution of tropospheric column $\mathrm{NO}_{2}$ between high and low dust emission periods. The domain-averaged OMI and WRFChem (Dust_JH) tropospheric column $\mathrm{NO}_{2}$ values over the geographical region $\left(70-80^{\circ} \mathrm{E}, 25-30^{\circ} \mathrm{E}\right)$ of maximum dust storm impact during low dust emission period are estimated 
as $(2.35 \pm 1.43) \times 10^{15}$ and $(3.95 \pm 2.43) \times 10^{15}$ molecules $\mathrm{cm}^{-2}$ respectively, and during high dust emission period are estimated as $(2.01 \pm 1.37) \times 10^{15}$ and $(3.41 \pm 2.80) \times 10^{15}$ molecules $\mathrm{cm}^{-2}$ respectively. The reduction in tropospheric column $\mathrm{NO}_{2}$ during high dust emission period in both OMI and WRF-Chem indicates that the dust storm acted as a sink for $\mathrm{NO}_{2}$.

\subsection{Impact of dust storm on photolysis rate coefficients}

The impact of the dust storm on photolysis rates is examined by comparing the daytime (07:30-17:30 IST or 02:0012:00 UTC) $\mathrm{NO}_{2}$ photolysis rate coefficients calculated by the WRF-Chem model with Dust_J and No_Dust configurations (Fig. 4). $\mathrm{NO}_{2}$ photolysis rates at the surface show a strong relationship with aerosol loading and are lowest over the Indo-Gangetic Plain region, which is where the anthropogenic emissions are stronger than those over other parts of the model domain. The inclusion of dust aerosols enhances the spatial heterogeneity of $\mathrm{NO}_{2}$ photolysis rate and decreases it by $5-25 \%$ over the Thar Desert and western Indo-Gangetic Plain region. The photolysis rate coefficients of other trace gases such as $\mathrm{O}_{3}, \mathrm{HNO}_{3}, \mathrm{H}_{2} \mathrm{O}_{2}, \mathrm{CH}_{2} \mathrm{O}$ and $\mathrm{N}_{2} \mathrm{O}_{5}$ at the surface exhibit similar features (not shown) with decreases of the same order of magnitude. The magnitude of change in photolysis rates decreases with altitude and changes sign from negative to positive near $4 \mathrm{~km}$ because of the increase in actinic flux due to scattering of incoming solar radiation by dust aerosol layers underneath. The spatial structure of changes in photolysis rates at $100 \mathrm{hPa}$ is similar to that at the surface with the largest increases (1-5\%) over the Thar Desert and western Indo-Gangetic Plain region.

\subsection{Impact of dust storm on trace gases at the surface}

To determine the impact of the dust storm on surface composition, average surface mixing ratios of $\mathrm{O}_{3}, \mathrm{SO}_{2}, \mathrm{NO}_{\mathrm{x}}$, $\mathrm{HNO}_{3}$ and $\mathrm{H}_{2} \mathrm{O}_{2}$ in the DUST_JH, which is the simulation that compared best with observations at Nainital, and the No_Dust simulation are compared for the dust event time period of 17-22 April 2010 (Fig. 5). Surface $\mathrm{O}_{3}$ shows a similar spatial distribution in both runs with the lowest values over the Arabian Sea and the highest values over the eastern Indo-Gangetic Plain region. However, the dust storm clearly leads to a reduction in $\mathrm{O}_{3}$ mixing ratios by $3-14 \mathrm{ppbv}$ (5-25\%) over the Thar Desert and western Indo-Gangetic Plain region. The spatial distribution of reductions in $\mathrm{O}_{3}$ mixing ratios is consistent with the distribution of dust over the model domain, and the amount of reduction is comparable to those reported by previous studies in dust source regions (e.g., Dentener et al., 1996; Tang et al., 2004; Pozzoli et al., 2008; Wang et al., 2012).

Sulfur dioxide and $\mathrm{NO}_{\mathrm{x}}$ mixing ratios are highest along the Indo-Gangetic Plain region due to higher emissions in this region (Fig. 5). Changes in $\mathrm{SO}_{2}$ mixing ratios show a mixed response to heterogeneous chemistry with a decrease of $0.1-0.2 \mathrm{ppbv}(8-10 \%)$ over the Thar Desert region and an increase of $0.2-0.5 \mathrm{ppbv}(2-6 \%)$ over the eastern IndoGangetic Plain region. This is because the heterogeneous chemistry reduces $\mathrm{SO}_{2}$ through reaction with dust particles while increases it through reduction of $\mathrm{OH}$ mixing ratios $\left(\mathrm{SO}_{2}+\mathrm{OH} \rightarrow\right.$ sulfate). The sign of the changes in $\mathrm{SO}_{2}$ is thus determined by competition between these two reactions. In general, $\mathrm{NO}_{\mathrm{x}}$ mixing ratios show a reduction of up to $0.5 \mathrm{ppbv}(<10 \%)$ along the Indo-Gangetic Plain region and $0.2-0.3$ ppbv (10-20\%) over the Thar Desert due to uptake of $\mathrm{NO}_{2}$ by dust particles. The changes in $\mathrm{NO}_{2}$ are also determined by the competition between the reactions of $\mathrm{NO}_{2}$ with dust and $\mathrm{OH}$ where the former tends to decrease $\mathrm{NO}_{2}$ while the latter tends to increase $\mathrm{NO}_{2}$ due to reduced $\mathrm{OH}$. The reduction in $\mathrm{NO}_{\mathrm{x}}$ is in contrast with the results of Wang et al. (2012), who reported an increase in $\mathrm{NO}_{\mathrm{x}}$ in the dust source region and attributed the increase to the renoxification process. Our study differs because Wang et al. (2012) assumed that renoxification process is active all the time, whereas this process is active only during daytime in our simulations. To quantify the contribution of renoxification process in the $\mathrm{NO}_{\mathrm{x}}$ budget, we compared the $\mathrm{NO}_{\mathrm{x}}$ distributions simulated by Dust_JH and Dust_JH_NoReNO ${ }_{\mathrm{x}}$ configurations. The comparison (not shown) showed that the renoxification process does increase $\mathrm{NO}_{\mathrm{x}}$ mixing ratios, but the magnitude of this increase (0.1-0.2 ppbv) is likely less than the reduction due to heterogeneous chemistry.

The spatial distributions of $\mathrm{HNO}_{3}$ and $\mathrm{H}_{2} \mathrm{O}_{2}$ (Fig. 5) are largely modified by the dust storm with reduction of up to 2 ppbv ( $\sim 99 \%)$, because these species are highly reactive with dust particles (Table 1). The large reduction in $\mathrm{H}_{2} \mathrm{O}_{2}$ mixing ratio estimated here is also in contrast with the results of Wang et al. (2012), who estimated an increase in $\mathrm{H}_{2} \mathrm{O}_{2}$. Wang et al. (2012) assumed a $100 \%$ yield for the conversion of $\mathrm{HO}_{2}$ into $\mathrm{H}_{2} \mathrm{O}_{2}$ through heterogeneous uptake, while we assume a yield of $10 \%$ following recent work by Bedjanian et al. (2013b). Mixing ratios of $\mathrm{NO}_{3}, \mathrm{~N}_{2} \mathrm{O}_{5}$ and $\mathrm{CH}_{3} \mathrm{COOH}$ also show large reductions by Dust_JH with the highest decrease reaching up to $0.1 \mathrm{ppbv}(\sim 98 \%), 0.46 \mathrm{ppbv}(\sim 99 \%)$ and $0.45 \mathrm{ppbv}(\sim 96 \%)$ respectively. The uptake of $\mathrm{HO}_{2}$ by dust particles leads to a maximum reduction of about $3.5 \mathrm{pptv}$ ( $\sim 40 \%)$ over the Thar Desert region, which is much less than those reported previously (e.g., Bian and Zender, 2003; Wang et al., 2012) and is attributed to a lower $\gamma$ value used in our study $(<0.064$ vs. 0.1$)$. The maximum reduction in $\mathrm{OH}$, $\mathrm{CH}_{2} \mathrm{O}$ and $\mathrm{CH}_{3} \mathrm{OH}$ is estimated to be about 40,21 and $5 \%$, respectively.

The above discussion includes both the role of heterogeneous chemistry in changing the distribution of trace gases and dust-modified photolysis rate coefficients. The individual contributions of heterogeneous chemistry and perturbation in photolysis rate coefficients to the total difference in distributions of trace gases at the surface are estimated by comparing differences between simulations (Fig. 6). More 


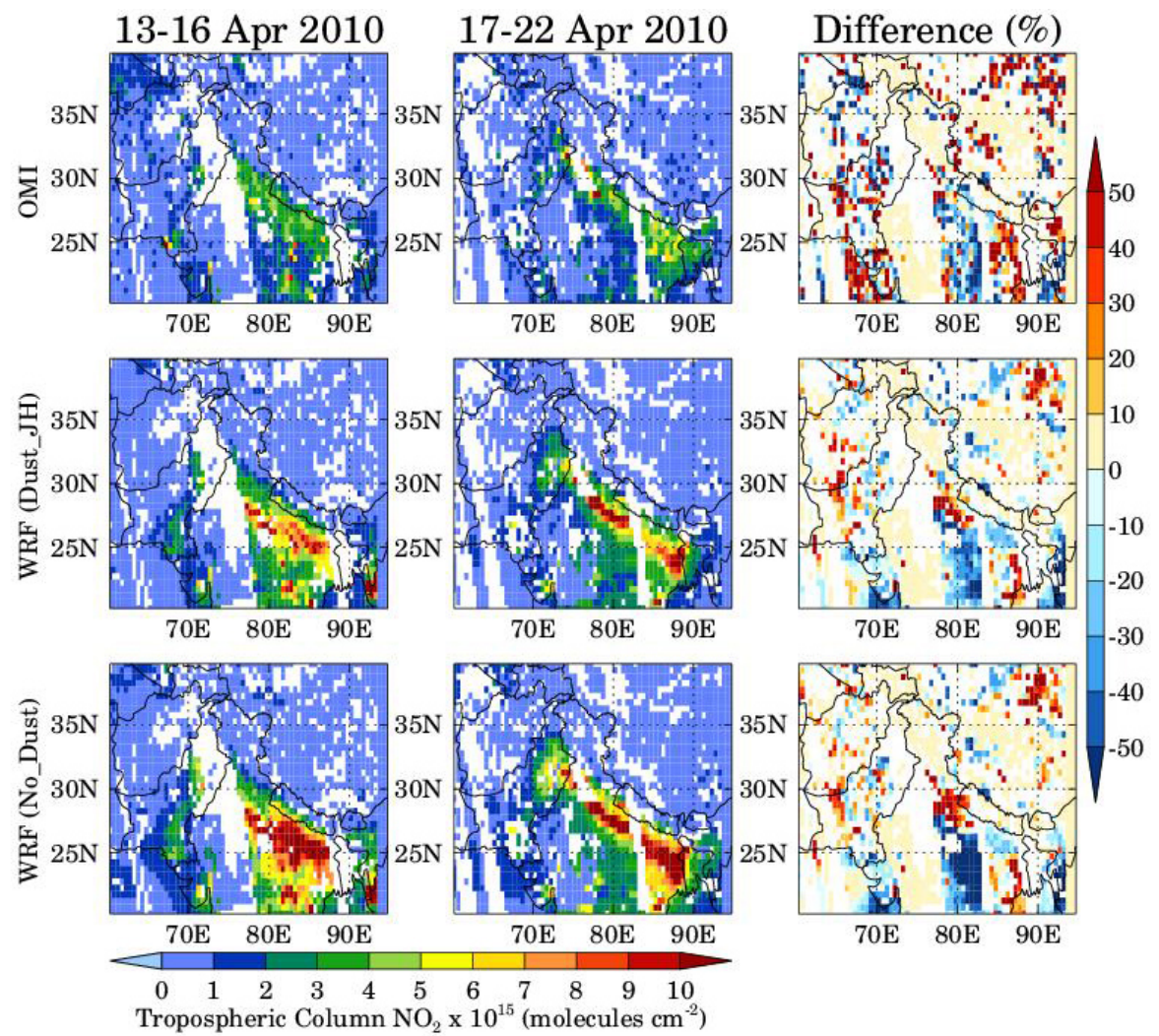

Figure 3. Spatial distributions of OMI-retrieved and WRF-Chem-simulated (Dust_JH and No_Dust) tropospheric column $\mathrm{NO}_{2}$ during the low (13-16 April 2010) and high (17-22 April 2010) dust emission periods. WRF-Chem profiles are convolved with OMI averaging kernels before comparison. The percentage differences between low and high dust emission periods are also shown.
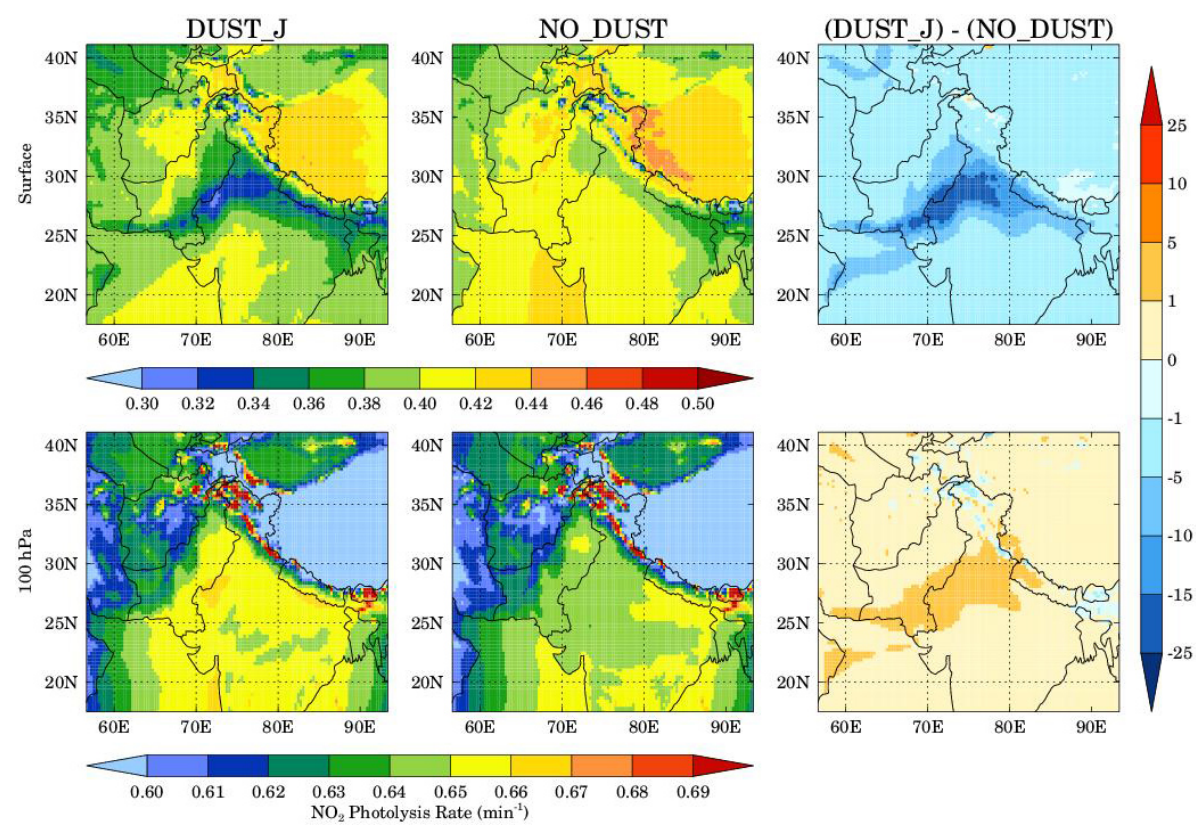

Figure 4. Spatial distributions of the WRF-Chem-simulated daytime (02:00-12:00 UTC) $\mathrm{NO}_{2}$ photolysis rate with (Dust_J) and without dust (No_Dust) at the surface (top panel) and $100 \mathrm{hPa}$ (bottom panel) during 17-22 April 2010 are shown. Percentage differences between Dust_J and No_Dust cases are also shown. 

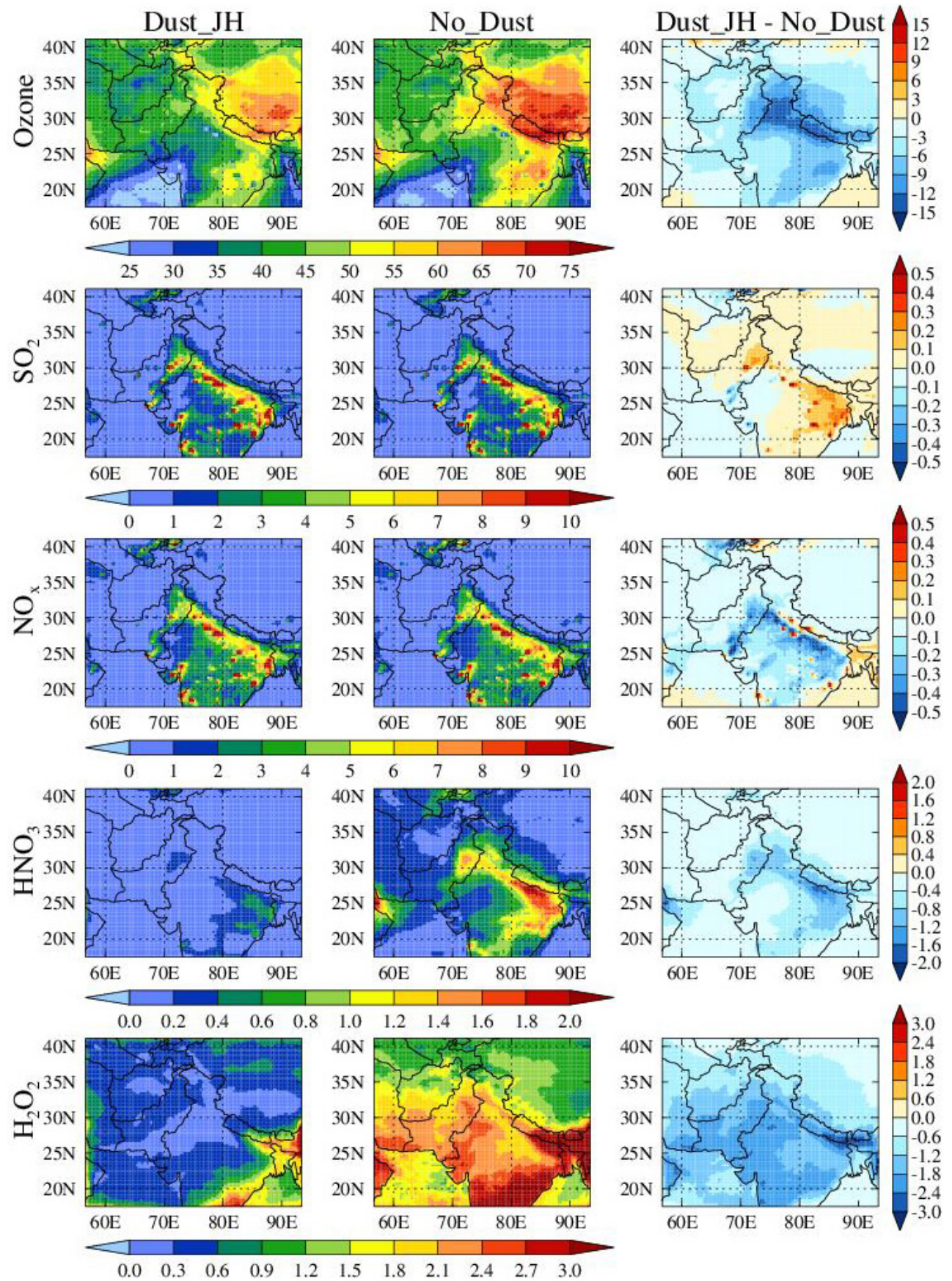

Figure 5. Spatial distributions of average surface $\mathrm{O}_{3}, \mathrm{SO}_{2}, \mathrm{NO}_{\mathbf{x}}, \mathrm{HNO}_{3}$ and $\mathrm{H}_{2} \mathrm{O}_{2}$ mixing ratios simulated by WRF-Chem with Dust_JH and No_Dust configuration during 17-22 April 2010. The absolute difference between the two configurations is also shown. All values are in ppbv.

than $80 \%$ of the changes in distribution of these trace gases are explained by the heterogeneous chemistry. The changes in surface $\mathrm{O}_{3}$ induced by dust-modified photolysis rate coefficients are within $\pm 1-3$ ppbv and are driven by the complex response of $\mathrm{O}_{3}$ to decreases in photolysis rate coefficients. A decrease in the photolysis rate coefficients leads to slower photochemical processing in general and thus decreased $\mathrm{O}_{3}$ production.

Mixing ratios of surface $\mathrm{SO}_{2}$ and $\mathrm{NO}_{\mathrm{x}}$ show an increase of up to $0.1 \mathrm{ppbv}$ due to reduction in photolysis rate coefficients. The increase in $\mathrm{NO}_{\mathrm{x}}$ and $\mathrm{SO}_{2}$ is associated with a decrease in $\mathrm{OH}$ mixing ratios as reaction with $\mathrm{OH}$ is the main loss process for both $\mathrm{NO}_{\mathrm{x}}$ and $\mathrm{SO}_{2}$. The decrease in $\mathrm{O}_{3}$ 

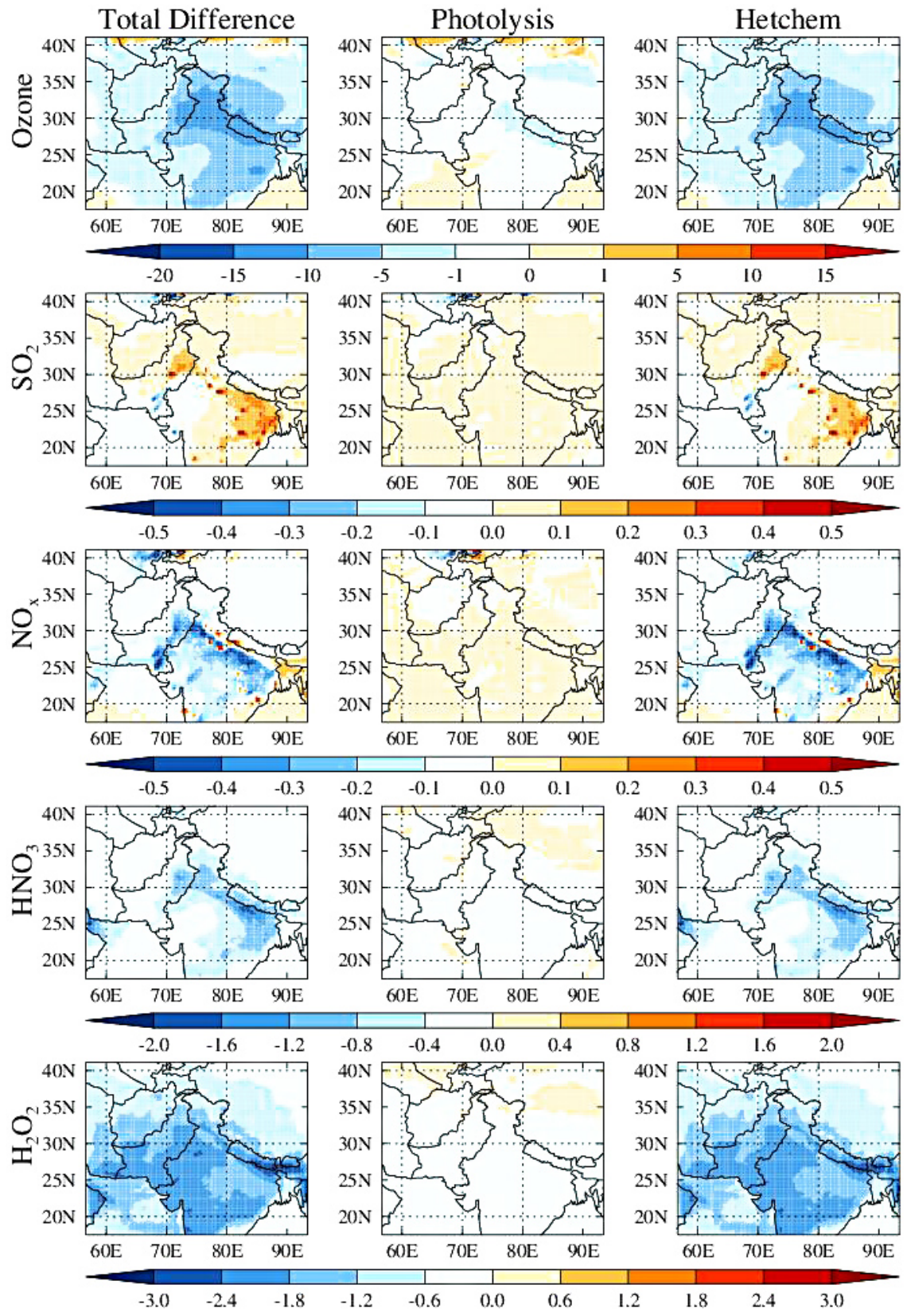

Figure 6. Spatial distributions of absolute difference in average $\mathrm{O}_{3}, \mathrm{SO}_{2}, \mathrm{NO}_{\mathrm{x}}, \mathrm{HNO}_{3}$ and $\mathrm{H}_{2} \mathrm{O}_{2}$ between Dust_JH and No_Dust (left panel), Dust_J and No_Dust representing the contribution of photolysis to total difference (middle panel), and Dust_JH and Dust_J representing the contribution of heterogeneous chemistry to total differences (right panel). All values are in ppbv and for the surface layer of the model.

photolysis rate coefficient leads to a decrease of up to $30 \%$ in $\mathrm{OH}\left(\mathrm{O}_{3}+h v \rightarrow \mathrm{O}^{1} \mathrm{D}+\mathrm{O}_{2}\right.$, producing $\mathrm{OH}$ through reaction of $\mathrm{O}^{1} \mathrm{D}$ with water vapor) mixing ratios. Mixing ratios of surface $\mathrm{HNO}_{3}$ and $\mathrm{H}_{2} \mathrm{O}_{2}$ also show a small decrease of up to 0.4 and $0.6 \mathrm{ppbv}$ in the Dust_ $\mathrm{J}$ configuration relative to the No_Dust configuration. $\mathrm{HNO}_{3}$ is produced mainly by the reaction of $\mathrm{OH}$ with $\mathrm{NO}_{2}$, but the rate of change of $\mathrm{HNO}_{3}$ is dominated by changes in $\mathrm{OH}$ as the reduction in $\mathrm{OH}$ (up to $30 \%$ ) is larger than that in $\mathrm{NO}_{2}$ (up to $5 \%$ ). The reduction in $\mathrm{H}_{2} \mathrm{O}_{2}$ is also associated with reduction in $\mathrm{OH}$ and $\mathrm{HO}_{2}$ mixing ratios. Since $\mathrm{OH}$ is the major oxidizing agent in the troposphere, a decrease in $\mathrm{OH}$ also leads to a decrease in the oxidizing capacity of the atmosphere and a consequent increase of up to $5-10 \%$ in several trace gases such as $\mathrm{CO}$, alkanes and alkenes at the surface. 

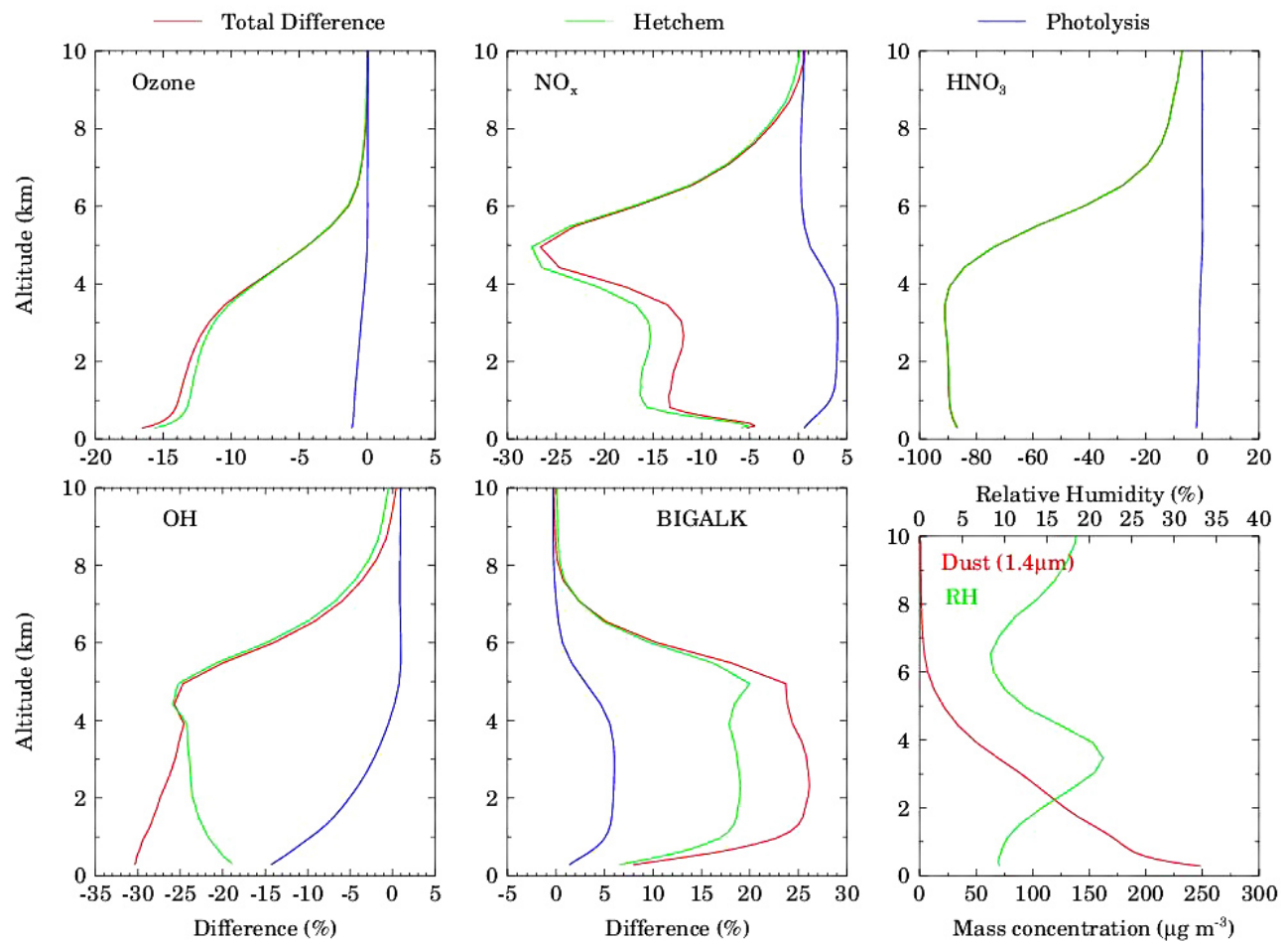

Figure 7. Vertical profiles of percentage total difference (red lines) in average $\mathrm{O}_{3}, \mathrm{NO}_{\mathrm{x}}, \mathrm{HNO}_{3}, \mathrm{OH}$ and BIGALK between Dust_JH and No_Dust configuration over the geographical region $\left(70-80^{\circ} \mathrm{E}, 25-30^{\circ} \mathrm{N}\right)$ of maximum dust influence. The contributions of heterogeneous chemistry (green lines) and photolysis (blue lines) to the total percentage difference are also shown. The vertical profiles of dust mass mixing ratios for particles of $1.4 \mu \mathrm{m}$ effective radius and relative humidity are also shown to help interpretation.

\subsection{Impact of dust storm on vertical distribution of trace gases}

In addition to changes in surface mixing ratios, vertical distributions of trace gases are modified by the dust storm via heterogeneous chemistry and dust-modified photolysis rates. By averaging over the region of maximum dust influence (70$80^{\circ} \mathrm{E}, 25-30^{\circ} \mathrm{N}$ ) for each simulation, the percentage differences between Dust_JH and No_Dust giving the total difference, Dust_J and No_Dust giving the contribution of modified photolysis rates, and Dust_JH and Dust_J giving the contribution from heterogeneous chemistry are found. Profiles of $\mathrm{O}_{3}, \mathrm{NO}_{\mathrm{x}}, \mathrm{HNO}_{3}, \mathrm{OH}$ and BIGALK are shown in Fig. 7. BIGALK represents alkanes with four or more carbon atoms in the MOZCART chemical mechanism and is shown to illustrate the dust-storm-induced changes in volatile organic compounds.

The changes in all the trace gases due to heterogeneous chemistry are much larger than those due to perturbations in photolysis rate coefficients, and are significant below $8 \mathrm{~km}$, which is consistent with the vertical distribution of dust particles (Fig. 7). All gases except BIGALK show a net reduction because of the larger changes induced by the heterogeneous chemistry. The reduction in $\mathrm{OH}$ due to decrease in $\mathrm{O}_{3}$ photolysis rate coefficient leads to a small increase of $1-4 \%$ in $\mathrm{NO}_{\mathrm{x}}$. The reaction with $\mathrm{OH}$ is the only loss process for BIGALK, and therefore BIGALK shows an increase due to both heterogeneous chemistry and perturbation in photolysis rates as both of these processes lead to a decrease in $\mathrm{OH}$. The highest net decreases in $\mathrm{O}_{3}, \mathrm{NO}_{\mathrm{x}}, \mathrm{HNO}_{3}$ and $\mathrm{OH}$ are estimated as $\sim 16, \sim 26, \sim 91$ and $\sim 30 \%$ respectively while the highest net increase in BIGALK is estimated as $\sim 26 \%$. The vertical distributions of changes in $\mathrm{NO}_{3}, \mathrm{~N}_{2} \mathrm{O}_{5}, \mathrm{H}_{2} \mathrm{O}_{2}$ and $\mathrm{CH}_{3} \mathrm{COOH}$ are similar to those in $\mathrm{HNO}_{3}$, and the highest net reduction reaches $80-90 \%$.

\subsection{Importance of $\mathrm{RH}$ dependence of reactive uptake coefficients $(\gamma)$}

The uptake of trace gases by dust aerosols also depends upon the relative humidity as reactive uptake coefficients have a large variation with $\mathrm{RH}$. The effect of relative humidity on the rate constants $k_{\mathrm{O}_{3}}$ and $k_{\mathrm{HNO}_{3}}$ at the surface over the model domain during 17-22 April 2010 is illustrated in Fig. 8, where model runs with and without RH dependence of $\gamma$ are compared. The spatial distributions of average mass concentration for dust particles of $1.4 \mu \mathrm{m}$ effective radius and relative humidity are also shown to help the interpretation. $\mathrm{RH}$ is less than $20 \%$ over most of the Indian region and is $70-90 \%$ over the oceanic regions. As expected, the spatial distributions of both $k_{\mathrm{O}_{3}}$ and $k_{\mathrm{HNO}_{3}}$ in both configurations are 


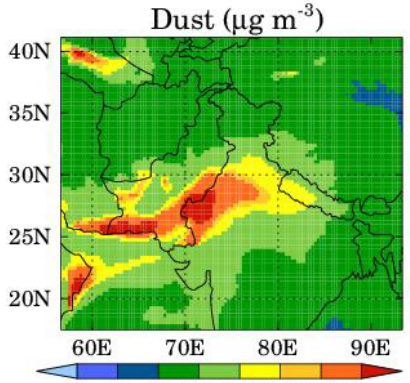

$15 \quad 10 \quad 50100150200500$ (Dust_JH)
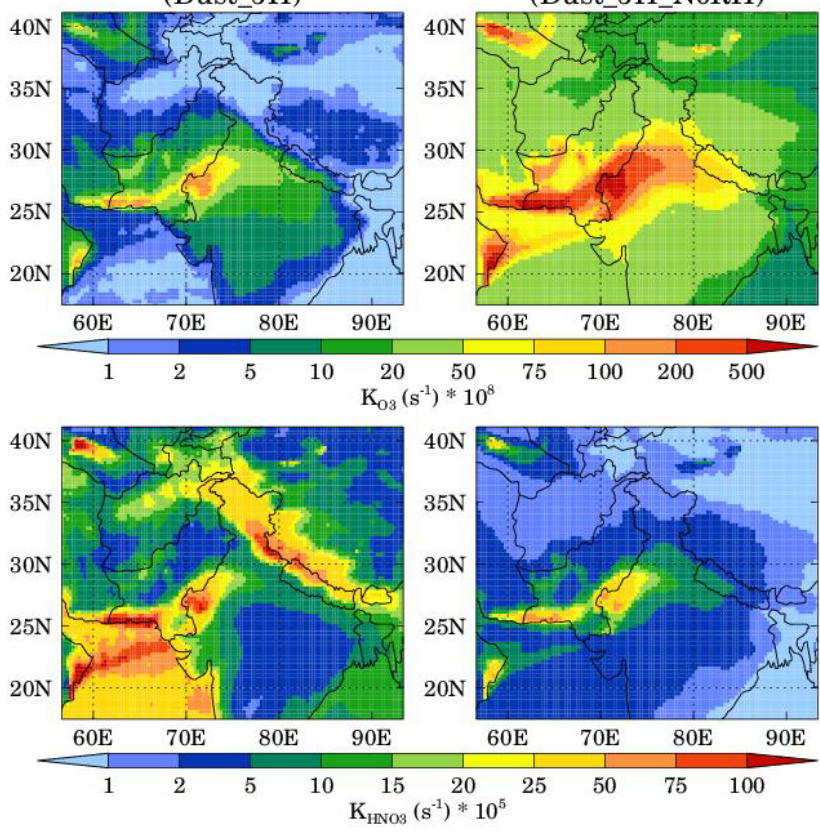

Figure 8. Spatial distributions of average mass concentration for dust particles of $1.4 \mu \mathrm{m}$ effective radius, relative humidity and pseudo-first-order rate coefficients for heterogeneous uptake of $\mathrm{O}_{3}\left(k_{\mathrm{O}_{3}}\right)$ and $\mathrm{HNO}_{3}\left(k_{\mathrm{HNO}_{3}}\right)$ by dust particles in Dust_JH and Dust_JH_NoRH configurations during 17-22 April 2010.

nearly identical to the distribution of dust mass concentrations with the highest values in the dust source regions. The rate constant decreases for $\mathrm{O}_{3}$ while it increases for $\mathrm{HNO}_{3}$ by 1-2 orders of magnitude after inclusion of RH dependence of $\gamma$. The rate coefficients for other gases show a similar spatial distribution.

The effect of RH-induced changes in the rate constants on heterogeneous uptake of $\mathrm{O}_{3}, \mathrm{SO}_{2}, \mathrm{HNO}_{3}, \mathrm{H}_{2} \mathrm{O}_{2}, \mathrm{OH}$ and $\mathrm{HO}_{2}$ is illustrated by showing the relative percentage differences in the distribution of these gases in the lowest model layer between the model runs with and without $\mathrm{RH}$ dependence of $\gamma$ (Fig. 9). Surface $\mathrm{O}_{3}$ and $\mathrm{HO}_{2}$ show an increase when $\mathrm{RH}$ effects on $\gamma$ are included because $\gamma$ for these gases decreases with $\mathrm{RH}$. In contrast, $\mathrm{HNO}_{3}$ and $\mathrm{H}_{2} \mathrm{O}_{2}$ uptake coefficients increase when $\mathrm{RH}$ effects are accounted for, resulting in a decrease in $\mathrm{HNO}_{3}$ and $\mathrm{H}_{2} \mathrm{O}_{2}$ mixing ra- tios. The changes in $\mathrm{O}_{3}, \mathrm{HO}_{2}$ and $\mathrm{H}_{2} \mathrm{O}_{2}$ reach up to 20,25 and $50 \%$, respectively, over the Thar Desert and the western Indo-Gangetic Plain region. The percentage changes in $\mathrm{HNO}_{3}$ reach up to $100 \%$ and are higher over the oceanic regions $(\mathrm{RH}>45 \%)$ than the inland regions because of the order of magnitude increase of $\gamma$ for $\mathrm{HNO}_{3}$ when $\mathrm{RH}$ increases above $40 \%$. Surface $\mathrm{SO}_{2}$ and $\mathrm{OH}$ show a mixed response with increase over some parts of the model domain and decrease over the others. The changes in $\mathrm{SO}_{2}$ and $\mathrm{OH}$ are within $\pm 10 \%$. The changes in $\mathrm{SO}_{2}$ are determined by the competition between the reactions of $\mathrm{SO}_{2}$ with dust particles and $\mathrm{OH}$. The heterogeneous reaction of $\mathrm{SO}_{2}$ tries to reduce $\mathrm{SO}_{2}$ due to increase in $\gamma$ with $\mathrm{RH}$ while that with $\mathrm{OH}$ would decrease (increase) $\mathrm{SO}_{2}$ if $\mathrm{OH}$ increases (decreases). The magnitudes of these $\mathrm{RH}$-induced changes in trace gases are comparable to those induced by heterogeneous chemistry (reported in Sect. 4.3). This suggests that consideration of $\mathrm{RH}$-dependent $\gamma$ values in heterogeneous chemistry calculations is as important as is the accurate simulation of dust mass concentrations.

\subsection{Effect of uncertainty in reactive uptake coefficient $(\gamma)$}

The effect of uncertainty in reactive uptake coefficient $(\gamma)$ on heterogeneous chemistry induced changes in the tropospheric chemistry is illustrated in Fig. 10, where model runs with lower (Dust_JH_LoG) and upper (Dust_JH_HiG) bounds of $\gamma$ are compared in the lowest model layer. It is clear that uncertainty in $\gamma$ can lead to significant uncertainty in heterogeneous chemistry induced changes in all gases. Surface $\mathrm{O}_{3}$ mixing ratios have uncertainties of up to 811 ppbv (25-30\%), while other gases have uncertainties of up to 1-1.5 ppbv (30-100\%), except $\mathrm{SO}_{2}$ and $\mathrm{NO}_{2}$, which show uncertainties of up to $3 \mathrm{ppbv}(30-70 \%)$ at some locations. A comparison of these uncertainties with the total change induced by dust storm in these gases (Fig. 5 and Sect. 4.3) reveals that uncertainties in $\mathrm{O}_{3}, \mathrm{HNO}_{3}, \mathrm{NO}_{3}$, $\mathrm{N}_{2} \mathrm{O}_{5}, \mathrm{OH}, \mathrm{HO}_{2}, \mathrm{H}_{2} \mathrm{O}_{2}$, and $\mathrm{CH}_{3} \mathrm{COOH}$ due to the uptake values have magnitudes similar to the total changes induced by dust aerosols, while those in $\mathrm{NO}_{2}, \mathrm{SO}_{2}$ and $\mathrm{CH}_{3} \mathrm{OH}$ are even greater than the total changes induced by dust storm. These results highlight the importance and necessity of accurate measurements of reactive uptake coefficients.

\subsection{Impact of dust aging}

The aging of dust particles through heterogeneous uptake of gases can modify the dust reactivity towards trace gases. We have made an attempt to simulate changes in the dust reactivity and uptake of trace gases due to nitrate and sulfate coating, and the results are presented in this section. The spatial distributions of WRF-Chem-simulated average mass concentration of fresh and aged dust particles of $1.4 \mu \mathrm{m}$ effective radius at the surface in Dust_JH_NO 3 , Dust_JH_SO 4 

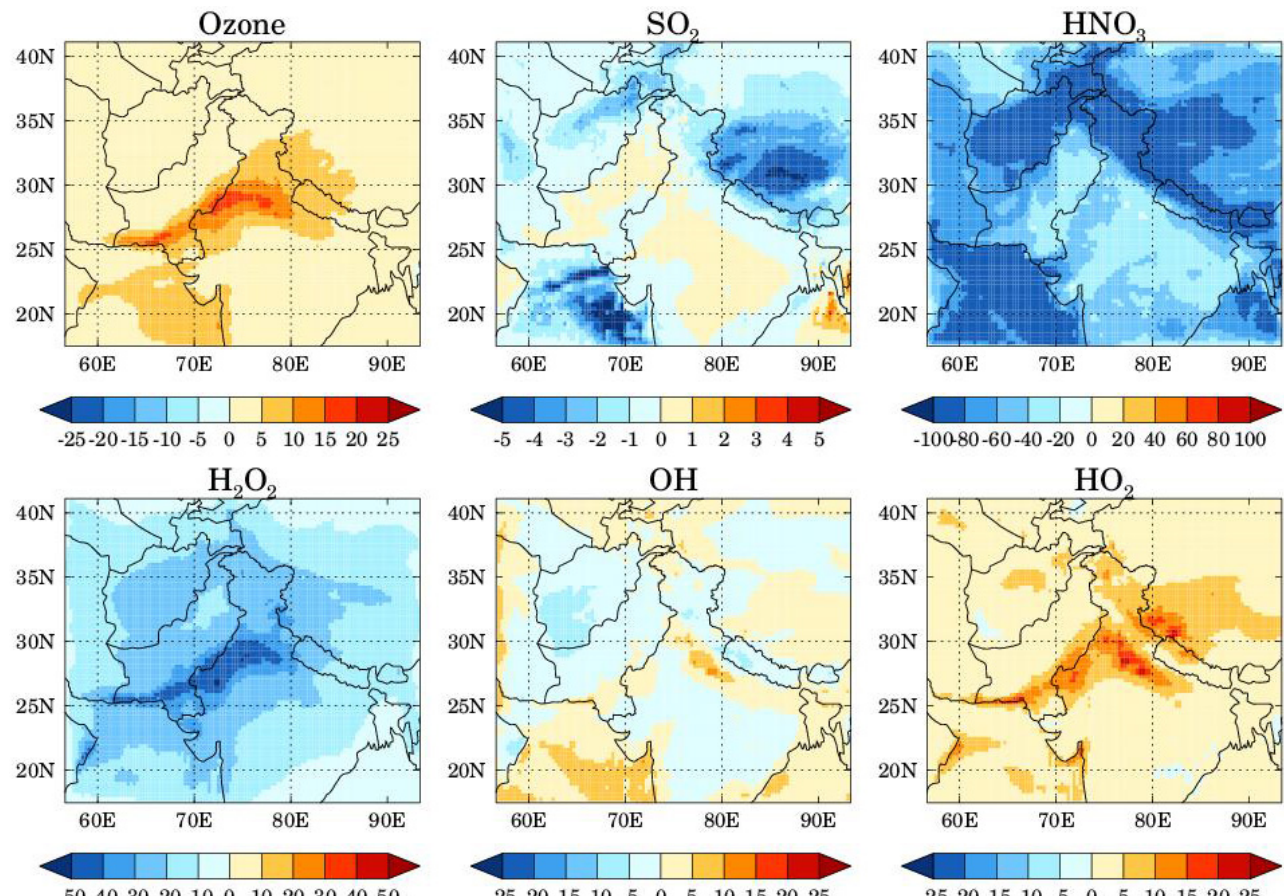

Figure 9. Spatial distributions of relative percentage differences in $\mathrm{O}_{3}, \mathrm{SO}_{2}, \mathrm{HNO}_{3}, \mathrm{H}_{2} \mathrm{O}_{2}, \mathrm{OH}$ and $\mathrm{HO}_{2}$ mixing ratios at the surface between Dust_JH and Dust_JH_NoRH configurations during 17-22 April 2010.

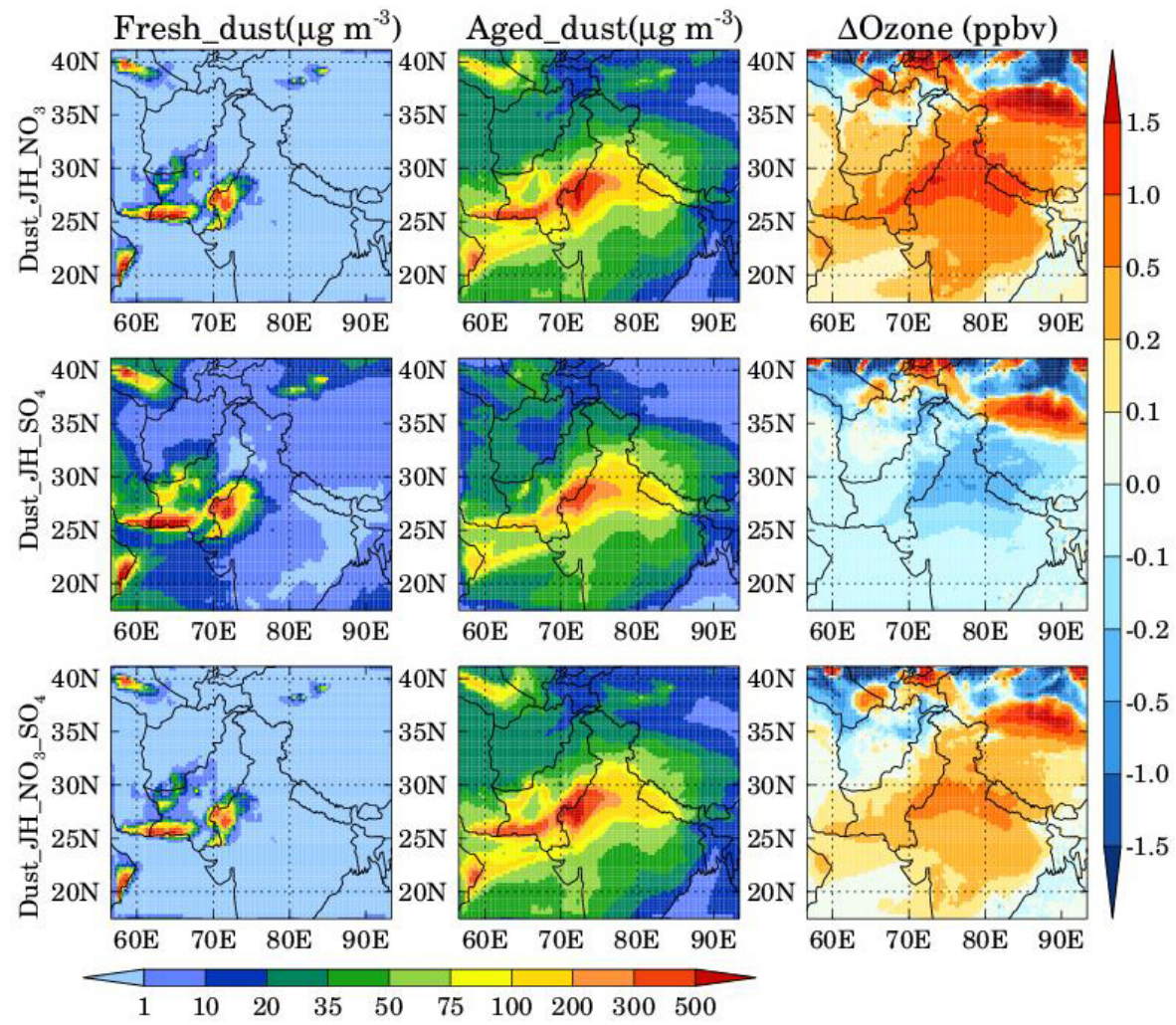

Figure 10. Spatial distributions of absolute differences in $\mathrm{O}_{3}, \mathrm{HNO}_{3}, \mathrm{NO}_{2}, \mathrm{SO}_{2}, \mathrm{CH}_{3} \mathrm{OH}$ and $\mathrm{CH}_{2} \mathrm{O}$ surface mixing ratios between Dust_JH_LoG and Dust_JH_HiG configurations during 17-22 April 2010. All values are in ppbv. 
and Dust_JH_NO $\mathrm{NO}_{3} \mathrm{SO}_{4}$ configurations during 17-22 April 2010 are shown in Fig. 11. In general, fresh dust particles are seen mostly in and near the source regions because all dust particles are emitted as fresh particles and have much smaller concentrations than the aged dust particles particularly outside the dust source regions. Among all the gases providing nitrate coating on dust particles, the $\mathrm{HNO}_{3}$ uptake makes the highest contribution to the concentration of aged particles due to its higher mixing ratios and strong increase in its reactivity towards the dust surface with relative humidity. For example, if there are 10 fresh dust particles $\mathrm{cm}^{-3}$ of effective radius $0.73 \mu \mathrm{m}$, then the uptake of $\mathrm{HNO}_{3}, \mathrm{NO}_{2}$, $\mathrm{NO}_{3}$ and $\mathrm{N}_{2} \mathrm{O}_{5}$ leads to about 2.5 aged dust particles $\mathrm{cm}^{-3}$ in one time step (180 s) at $\mathrm{RH}=0$, and $\mathrm{HNO}_{3}$ and $\mathrm{NO}_{3}$ each provide about 1 dust particle. However, the number concentration of aged dust particles formed due to $\mathrm{HNO}_{3}$ uptake increases to about 7 particles $\mathrm{cm}^{-3}$ per time step as $\mathrm{RH}$ increases to $20-40 \%$. The uptake of $\mathrm{SO}_{2}$ also increases with increase in relative humidity, but the $\mathrm{SO}_{2}$ contribution to the aged particles is much less than that of $\mathrm{HNO}_{3}$ due to lower $\mathrm{SO}_{2} \gamma$ values. The decrease in $\mathrm{O}_{3} \gamma$ values for nitrate-coated dust particles leads to an enhancement of 1-2 ppbv in surface $\mathrm{O}_{3}$ over the Thar Desert and western Indo-Gangetic Plain region relative to uncoated dust particles (Fig. 11) while increase in $\mathrm{O}_{3} \gamma$ values for sulfate-coated dust particles leads to a reduction of $0.5-1 \mathrm{ppbv}$ over these regions. Since nitrate coating leads to a larger fraction of aged particles than the sulfate coating, surface $\mathrm{O}_{3}$ mixing ratios show an overall enhancement of up to 1 ppbv over the regions of high dust loadings when both sulfate- and nitrate-coated dust particles are allowed to react with $\mathrm{O}_{3}$ in the model.

The presence of a nitrate or sulfate monolayer on the dust particle might saturate the dust particles and deactivate them for further catalytic uptake of other gases. In order to examine the effect of such a coating on the uptake of $\mathrm{O}_{3}, \mathrm{H}_{2} \mathrm{O}_{2}$, $\mathrm{HCHO}$ and $\mathrm{CH}_{3} \mathrm{COOH}$, lower and upper bounds of heterogeneous chemistry reaction rates induced changes in the surface mixing ratios of these gases are calculated (Fig. 12). Lower and upper bounds for each gas are calculated by subtracting their average values in Dust_J configuration from those in Dust_JH and Dust_JH_Sat configurations respectively. Absolute mixing ratios of these gases in Dust_J configuration, in which dust aerosols affected photolysis rates only, are also shown to provide an idea of the modification in base levels of these gases due to heterogeneous chemistry. As expected, the saturation of dust particles decreases the magnitude of reduction caused by heterogeneous chemistry for all the gases by $5-50 \%$. The amount of maximum reduction in surface $\mathrm{O}_{3}$ changed from $20-25 \%$ to $15-20 \%$ when saturation effects are accounted for. The saturation of dust particles has a larger impact on the distribution of $\mathrm{H}_{2} \mathrm{O}_{2}$ and $\mathrm{CH}_{3} \mathrm{COOH}$ as maximum reduction in both of these gases decreased to 20-40\% (as compared to 70-90\% for unsaturated dust particles) over the Thar Desert and dust source regions. Both of these gases show a small increase of $0.1-0.2 \mathrm{ppbv}$ (less than $10 \%$ ) outside the source regions for the case of saturated dust particles. The maximum reduction in $\mathrm{HO}_{2}$ and $\mathrm{OH}$ (not shown) also changes from $20-40 \%$ in Dust_JH to 5-20\% in Dust_JH_Sat. Some changes can also be discerned in the distribution of $\mathrm{HCHO}$ and $\mathrm{CH}_{3} \mathrm{OH}$ (not shown), but they are within $\pm 5 \%$.

\section{Summary}

The effects of a typical pre-monsoon season dust storm on tropospheric chemistry are analyzed for a case study in northern India, using the Weather Research and Forecasting model coupled with Chemistry (WRF-Chem), which is further developed to enhance its ability to simulate tropospheric chemistry in the presence of dust particles. The changes made to the model are specific to the MOZCART setup. Two major updates are included in this study: firstly, the F-TUV photolysis scheme of the model is updated to include the effect of dust aerosols on photolysis rates and to achieve consistency between the methods through which aerosols affect the meteorology and photolysis rates in the model. Secondly, a new scheme consisting of 12 heterogeneous reactions is included to simulate heterogeneous chemistry on the surface of dust particles. The relative humidity dependence of uptake coefficients, which was ignored in most previous studies, is used for six of the heterogeneous reactions.

The extended configuration of WRF-Chem is applied to a typical pre-monsoon season dust storm that occurred in northern India during 17-22 April 2010. The model reproduced the spatial and temporal distribution of dust plumes and aerosol optical properties (Kumar et al., 2014). The simulations are evaluated against surface $\mathrm{O}_{3}$ and $\mathrm{NO}_{\mathrm{y}}$ observations at a high-altitude $(1958 \mathrm{~m})$ measurement station in the Himalayan region (Nainital), and the model is found to capture the observed decrease in $\mathrm{O}_{3}$ and $\mathrm{NO}_{\mathrm{y}}$ during the dust storm only after the inclusion of the effects of dust on photolysis rates and heterogeneous chemistry. Average observed and modeled $\mathrm{O}_{3}$ values at Nainital during 17-22 April 2010 are estimated to be $56 \pm 10$ and $58 \pm 5$ ppbv respectively, and the corresponding $\mathrm{NO}_{\mathrm{y}}$ values are estimated to be $843 \pm 887$ and $1189 \pm 751 \mathrm{pptv}$ respectively. The extended configuration of the model also reduced biases in tropospheric column $\mathrm{NO}_{2}$ by up to $30 \%$ compared to OMI retrievals and captured the general features of the dust-storm-induced changes in the spatial distribution of OMI-retrieved tropospheric column $\mathrm{NO}_{2}$.

Several sensitivity simulations are conducted to investigate the contribution of different processes on mixing ratios of several key trace gases including ozone, nitrogen oxides, hydrogen oxides, methanol, acetic acid and formaldehyde. The dust storm leads to a decrease of 5-25\% in photolysis rate coefficients of $\mathrm{O}_{3}, \mathrm{NO}_{2}$ and other trace gases at the surface and an increase of $1-5 \%$ above $4 \mathrm{~km}$. It is found to have a significant impact on the regional tropospheric chemistry: a 

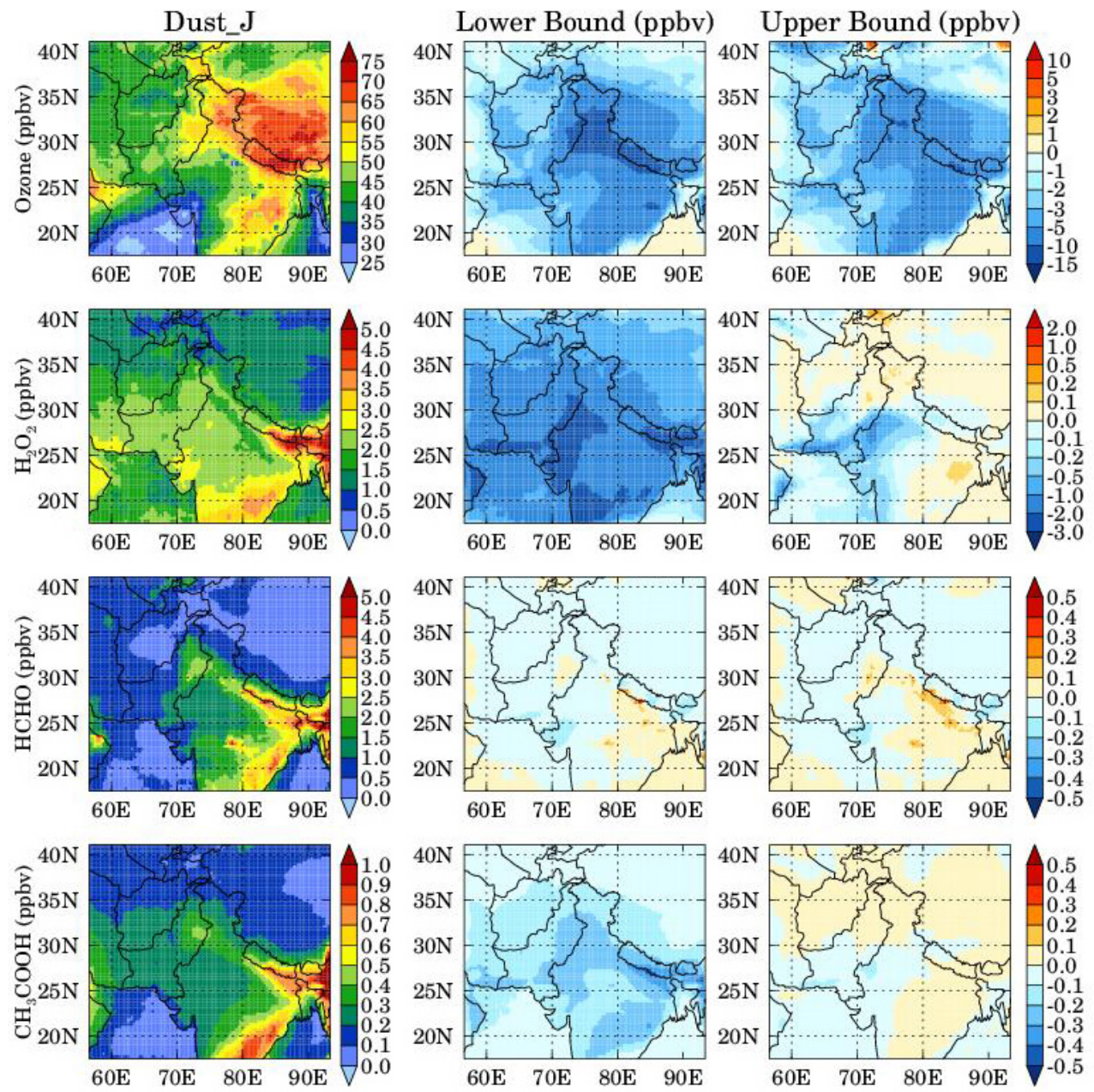

Figure 11. Spatial distributions of WRF-Chem-simulated average mass concentration of fresh and aged dust particles of $1.4 \mu \mathrm{m}$ effective radius at the surface in Dust_JH_NO ${ }_{3}$, Dust_JH_SO 4 and Dust_JH_NO ${ }_{3} \mathrm{SO}_{4}$ configurations during 17-22 April 2010. $\Delta \mathrm{O}_{3}$ is calculated by subtracting the average surface $\mathrm{O}_{3}$ in Dust_JH configuration from the corresponding average values in Dust_JH_NO 3 , Dust_JH_SO 4 and Dust_JH_NO $\mathrm{N}_{3} \mathrm{SO}_{4}$ configurations respectively.

decrease of 5-99\% is estimated in the mixing ratios of a variety of trace gases including $\mathrm{O}_{3}$, nitrogen oxides, hydrogen oxides, sulfur dioxide, methanol, acetic acid and formaldehyde at the surface. Analysis of the vertical distributions of these trace gases shows that dust-storm-induced changes are significant up to an altitude $8 \mathrm{~km}$ and are estimated as 80 $90 \%$ (5-10 times) for highly reactive gases such as $\mathrm{HNO}_{3}$, $\mathrm{NO}_{3}, \mathrm{~N}_{2} \mathrm{O}_{5}, \mathrm{H}_{2} \mathrm{O}_{2}$ and $\mathrm{CH}_{3} \mathrm{COOH}$. It is found that the majority of these changes are induced by the heterogeneous chemistry, while the contribution of dust-modified photolysis rates generally remained less than $10 \%$. An increase of up to $30 \%$ in volatile organic compounds is estimated due to decreases in $\mathrm{OH}$ concentrations.

The RH dependence of $\gamma$ is found to play a large potential role in heterogeneous chemistry. Sensitivity studies showed that the exclusion of the RH dependence can introduce a difference of 1-2 orders of magnitude in heterogeneous reac- tions rate constants, $20-25 \%$ changes in $\mathrm{O}_{3}$ and $\mathrm{HO}_{2}$, and up to 50 and $100 \%$ changes in $\mathrm{H}_{2} \mathrm{O}_{2}$ and $\mathrm{HNO}_{3}$, respectively. These effects are comparable to heterogeneous chemistry induced changes in these gases. The effect of uncertainties in the uptake coefficients $(\gamma)$ on the distribution of trace gases is examined using sensitivity simulations with lower and upper bounds of $\gamma$. Differences of trace gas mixing ratios caused by uncertainties in the uptake coefficients are found to be the same magnitude or greater as the differences in mixing ratios induced by dust storm effects on tropospheric chemistry. We also tested the importance of atmospheric aging of dust particles in the context of heterogeneous chemistry. Model experiments based on laboratory studies of changes in dust reactivity due to atmospheric aging showed that coating of dust with nitrate and sulfate may lead to changes of up to 1 ppbv in surface $\mathrm{O}_{3}$ simulations. A hypothetical simulation is also conducted by saturating the nitrate- and sulfate-coated 
dust particles for uptake of $\mathrm{O}_{3}, \mathrm{HO}_{2}, \mathrm{OH}, \mathrm{H}_{2} \mathrm{O}_{2}, \mathrm{CH}_{3} \mathrm{COOH}$, $\mathrm{CH}_{3} \mathrm{OH}$ and $\mathrm{HCHO}$. The saturation of dust particles is found to have a larger impact on the distributions of $\mathrm{H}_{2} \mathrm{O}_{2}$ and $\mathrm{CH}_{3} \mathrm{COOH}$ but a relatively small impact on other gases.

This study clearly shows that the pre-monsoon season dust storm can potentially affect the regional tropospheric chemistry in northern India. However, the implications of the heterogeneous uptake of trace gases on aerosol size distributions and their feedbacks on the radiation budget and cloudiness are not examined here. Dust particles coated with nitrate/sulfate may interact differently with radiation as compared to uncoated dust particles and can increase or decrease cloudiness depending upon their size distribution. Both of these processes will have important implications for the direct aerosol radiative forcing and the elevated heat pump (EHP) hypothesis (Lau et al., 2006), which proposed that the absorption of solar radiation by dust and black carbon aerosols along the southern slopes of Himalayas modulates the meridional temperature gradient and leads to an early onset of Indian summer monsoon. The heterogeneous chemistry scheme implemented in the MOZCART chemical mechanism here can be easily extended to a more detailed aerosol module (e.g., MOSAIC) of WRF-Chem, which would allow studies on the implications of heterogeneous chemistry for aerosols and their interaction with radiation, clouds, and the Asian monsoon, including the role of aerosol aging on aerosol and trace gas distributions.

Nevertheless, this study demonstrates that the effects of dust aerosols through heterogeneous chemistry and perturbation in photolysis rates should be included in atmospheric chemistry transport models, especially for simulating air quality in northern India. Although this study analyzed a typical dust storm in northern India, but more such studies should be conducted in future to lend further confidence in these results. At the same time, it is also imperative to improve the accuracy and precision of the reactive uptake coefficients, their dependence on relative humidity and atmospheric processing of dust particles. In addition, extensive efforts must be made to conduct co-located measurements of $\mathrm{O}_{3}$ and related gases, along with physical and chemical properties of dust aerosols in northern India, especially during the dust storm season, to gain insights into the effects of dust aerosols on tropospheric chemistry and provide more data for model evaluation.

\section{The Supplement related to this article is available online} at doi:10.5194/acp-14-6813-2014-supplement.
Acknowledgements. We thank L. Emmons and C. Wiedinmyer for their constructive suggestions on the manuscript. The data sets of initial and boundary conditions for meteorological fields were made available by the NCAR research data archive (http://rda.ucar.edu/datasets/ds083.2/). The data sets for initial and boundary conditions for chemical fields, biogenic emissions, biomass burning emissions, and programs used to process these data sets were made available by the NCAR Atmospheric Chemistry Division (http://www.acd.ucar.edu/wrf-chem/). We thank the OMI science team at KNMI for providing tropospheric $\mathrm{NO}_{2}$ retrievals. The National Center for Atmospheric Research is supported by the National Science Foundation. Observations at Nainital are supported by ISRO-ATCTM project. Comments from the two reviewers are greatly appreciated.

Edited by: H. Tost

\section{References}

Bauer, S. E., Balkanski, Y., Schulz, M., Hauglustaine, D. A., and Dentener, F.: Global modeling of heterogeneous chemistry on mineral aerosol surfaces: Influence on tropospheric ozone chemistry and comparison to observations, J. Geophys. Res., 109, D02304, doi:10.1029/2003JD003868, 2004.

Bedjanian, Y., Romanias, M. N., and El Zein, A.: Interaction of $\mathrm{OH}$ Radicals with Arizona Test Dust: Uptake and Products, J. Phys. Chem. A, 117, 393-400, doi:10.1021/jp311235h, 2013a.

Bedjanian, Y., Romanias, M. N., and El Zein, A.: Uptake of $\mathrm{HO}_{2}$ radicals on Arizona test dust surface, Atmos. Chem. Phys. Discuss., 13, 8873-8900, doi:10.5194/acpd-13-8873-2013, 2013b.

Beljaars, A. C. M.: The parameterization of surface fluxes in largescale models under free convection, Q. J. Roy. Meteor. Soc., 121, 255-270, 1994.

Bian, H. and Zender, C. S.: Mineral dust and global tropospheric chemistry: Relative roles of photolysis and heterogeneous uptake, J. Geophys. Res., 108, 4672, doi:10.1029/2002JD003143, 2003.

Boersma, K. F., Jacob, D. J., Bucsela, E. J., Perring, A. E., Dirksen, R., vander A, R. J., Yantosca, R. M., Park, R. J., Wenig, M. O., Bertram, T. H., and Cohen, R. C.: Validation of OMI tropospheric $\mathrm{NO}_{2}$ observations during INTEX-B and application to constrain $\mathrm{NO}_{\mathrm{x}}$ emissions over the eastern United States and Mexico, Atmos. Environ., 42, 4480-4497, 2008.

Boersma, K. F., Jacob, D. J., Trainic, M., Rudich, Y., DeSmedt, I., Dirksen, R., and Eskes, H. J.: Validation of urban $\mathrm{NO}_{2}$ concentrations and their diurnal and seasonal variations observed from the SCIAMACHY and OMI sensors using in situ surface measurements in Israeli cities, Atmos. Chem. Phys., 9, 3867-3879, doi:10.5194/acp-9-3867-2009, 2009a.

Boersma, K. F., Dirksen, R. J., Veefkind, J. P., Eskes, H. J., and van der A, R. J.: Dutch OMI NO 2 (DOMINO) data product, HE5 data file user manual, http://www.temis.nl/docs/OMINO2HE51. 0.2.pdf, 2009b.

Bucsela, E. J., Celarier, E. A., Wenig, M. O., Gleason, J. F., Veefkind, J. P., Boersma, K. F., and Brinksma, E. J.: Algorithm for $\mathrm{NO}_{2}$ vertical column retrieval from the ozone monitoring instrument, IEEE T. Geosci. Remote, 44, 1245-1258, 2006.

Chen, F. and Dudhia, J.: Coupling and advanced land surface hydrology model with the Penn State-NCAR MM5 modelingsys- 
tem, Part I: Model implementation and sensitivity, Mon. Weather Rev., 129, 569-585, 2001.

Chen, H., Navea, J. G., Young, M. A., and Grassian, V.H.: Heterogeneous Photochemistry of Trace Atmospheric Gases with Components of Mineral Dust Aerosol, J. Phys. Chem. A, 115, 490-499, 2011

Chin, M., Ginoux, P., Kinne, S., Holben, B. N., Duncan, B. N., Martin, R. V., Logan, J. A., Higurashi, A., and Nakajima, T.: Tropospheric aerosol optical thickness from the GOCART model and comparisons with satellite and sunphotometer measurements, J. Atmos. Sci., 59, 461-483, 2002.

Crowley, J. N., Ammann, M., Cox, R. A., Hynes, R. G., Jenkin, M. E., Mellouki, A., Rossi, M. J., Troe, J., and Wallington, T. J.: Evaluated kinetic and photochemical data for atmospheric chemistry: Volume V - heterogeneous reactions on solid substrates, Atmos. Chem. Phys., 10, 9059-9223, doi:10.5194/acp-10-90592010, 2010.

Cwiertny, D. M., Young, M. A., and Grassian, V. H.: Chemistry and photochemistry of mineral dust aerosol, Annu. Rev. Phys. Chem., 59, 27-51, doi:10.1146/annurev.physchem.59.032607.093630, 2008.

DeFries, R. S. and Townshend, J. R. G.: NDVI-derived land cover classification at a global scale, Int. J. Remote Sens., 15, 35673586, 1994.

Dentener, F. J., Carmichael, G. R. , Zhang, Y., Lelieveld, J., and Crutzen, P. J.: Role of mineral aerosol as a reactive surface in the global troposphere, J. Geophys. Res, 101, 22869-22889, 1996.

Dey, S., Tripathi, S. N., Singh, R. P., and Holben, B. N.: Influence of dust storms on aerosol opticalproperties over the Indo-Gangetic basin, J. Geophys. Res., 109, D20211, doi:10.1029/2004JD004924, 2004.

Emmons, L. K., Deeter, M. N., Gille, J. C., Edwards, D. P., Attié, J.-L., Warner, J., Ziskin, D., Francis, G., Khattatov, B., Yudin, V., Lamarque, J.-F., Ho, S.-P., Mao, D., Chen, J. S., Drummond, J., Novelli, P., Sachse, G., Coffey, M. T., Hannigan, J. W., Gerbig, C., Kawakami, S., Kondo, Y., Takegawa, N., Schlager, H., Baehr, J., and Ziereis, H.: Validation of Measurements of Pollution in the Troposphere (MOPITT) CO retrievals with aircraft in situ profiles, J. Geophys. Res., 109, D03309, doi:10.1029/2003JD004101, 2004.

Emmons, L. K., Walters, S., Hess, P. G., Lamarque, J.-F., Pfister, G. G., Fillmore, D., Granier, C., Guenther, A., Kinnison, D., Laepple, T., Orlando, J., Tie, X., Tyndall, G., Wiedinmyer, C., Baughcum, S. L., and Kloster, S.: Description and evaluation of the Model for Ozone and Related chemical Tracers, version 4 (MOZART-4), Geosci. Model Dev., 3, 43-67, doi:10.5194/gmd3-43-2010, 2010.

Fast, J. D, Gustafson Jr., W. I., Easter, R. C., Zaveri, R. A., Barnard, J. C., Chapman, E. G., and Grell, G. A.: Evolution of ozone, particulates, and aerosol direct forcing in an urban area using anew fully-coupled meteorology, chemistry, and aerosol model, J. Geophys. Res., 111, D21305, doi:10.1029/2005JD006721, 2006.

Freitas, S. R., Longo, K. M., Chatfield, R., Latham, D., Silva Dias, M. A. F., Andreae, M. O., Prins, E., Santos, J. C., Gielow, R., and Carvalho Jr., J. A.: Including the sub-grid scale plume rise of vegetation fires in low resolution atmospheric transport models, Atmos. Chem. Phys., 7, 3385-3398, doi:10.5194/acp-7-3385-2007, 2007.
Ghude, S. D., Pfister, G. G., Jena, C., van der A, R. J., Emmons, L. K., and Kumar, R.: Satellite constraints of nitrogen oxide $\left(\mathrm{NO}_{\mathrm{x}}\right)$ emissions from India based on OMI observations and WRF-Chem simulations, Geophys. Res. Lett., 40, 423-428, doi:10.029/2012GL053926, 2013.

Ginoux, P., Chin, M., Tegen, I., Prospero, J. M., Holben, B., Dubovik, O., and Lin, S. J.: Sources and distributions of dust aerosols simulated with the GOCART model, J. Geophys. Res.Atmos., 106, 20255-20273, 2001.

Goodman, A. L., Underwood, G. M., and Grassian, V. H.: A laboratory study of the heterogeneous reaction of nitric acid on calcium carbonate particles, J. Geophys. Res., 105, 29053-29064, 2000.

Granier, C. Bessagnet, B., Bond, T., D’Angiola, A., van der Gon, H. G., Frost, G. J., Heil, A., Kaiser, J. W., Kinne, S., Klimont, Z., Kloster, S., Lamarque, J.-F., Liousse, C., Masui, T., Meleux, F., Mieville, A., Ohara, T., Raut, J.-C., Riahi, K., Schultz, M. G., Smith, S. J., Thompson, A., van Aardenne, J., van der Werf, G. R., and van Vuuren, D. P.: Evolution of anthropogenic and biomass burning emissions of air pollutants at global and regional scales during the 1980-2010 period, Clim. Change, 109, 163-190, doi:10.1007/s10584-011-0154-1, 2011.

Grassian, V. H.: Chemical reactions of nitrogen oxides on the surface of oxide, carbonate, soot, and mineral dust particles: implications for the chemical balance of the troposphere, J. Phys. Chem. A, 106, 860-877, doi:10.1021/jp012139h, 2002.

Grell, G. A., Peckham, S. E., Schmitz, R., McKeen, S. A., Frost, G., Skamarock, W. C., and Eder, B.: Fully coupled "online" chemistry within the WRF model, Atmos. Environ., 39, 6957-6975, 2005.

Guenther, A., Karl, T., Harley, P., Wiedinmyer, C., Palmer, P. I., and Geron, C.: Estimates of global terrestrial isoprene emissions using MEGAN (Model of Emissions of Gases and Aerosols from Nature), Atmos. Chem. Phys., 6, 3181-3210, doi:10.5194/acp-63181-2006, 2006.

Hatch, D. C., Gierlus, K. M., Schuttlefeld, J. D., and Grassian, V. H.: Water adsorption and cloud condensation nuclei activity of calcite and calcite coated with model humic and fulvic acids, Atmos. Environ., 42, 5672-5684, 2008.

Haywood, J. and Boucher, O.: Estimates of the direct and indirect radiative forcing due to tropospheric aerosols: a review, Rev. Geophys., 38, 513-543, 2000

Hegde, P., Pant, P., Naja, M., Dumka, U. C., and Sagar, R.: South Asian dust episode in June 2006: Aerosol observations in the central Himalayas, Geophys. Res. Lett., 34, L23802, doi:10.1029/2007GL030692, 2007.

Heikes, B. G. and Thompson, A. M.: Effects of heterogeneous processes on $\mathrm{NO}_{3}, \mathrm{HONO}$ and $\mathrm{HNO}_{3}$ chemistry in the troposphere, J. Geophys. Res., 88, 10883-10895, 1983.

Hodzic, A., Bessagnet, B., and Vautard, R.: A model evaluation of coarse-mode nitrate heterogeneous formation on dust particles, Atmos. Environ., 40, 4158-4171, 2006.

Hong, S.-Y., Yign N., and Dudhia, J.: A new vertical diffusion package with an explicit treatment of entrainment processes, Mon. Weather Rev., 134, 2318-2341, 2006.

Jacobson, M. Z.: Fundamentals of Atmospheric Modeling, 2nd Edn., Cambridge University Press, New York, 2005.

Jickells, T. D., An, Z. S., Andersen, K. K., Baker, A. R., Bergametti, G., Brooks, N., Cao, J. J., Boyd, P. W., Duce, R. A., Hunter, K A., Kawahata, H., Kubilay, N., laRoche, J., Liss, P. S., Mahowald, 
N., Prospero, J. M., Ridgwell, A. J., Tegen, I., and Torres, R.: Global iron connections between desert dust, ocean biogeochemistry and climate, Science, 308, 67-71, 2005.

Kain, J. S.: The Kain-Fritsch convective parameterization: An update, J. Appl. Meteorol., 43, 170-181, 2004.

Kelly, J. T., Chuang, C. C., and Anthony, S. W.: Influence of dust composition on cloud droplet formation, Atmos. Environ., 41, 2904-2904, 2007.

Kramer, L. J., Leigh, R., Remedios, J. J., and Monks, P. S.: Comparison of OMI and ground-based in situ and MAX-DOAS measurements of tropospheric nitrogen dioxide in an urban area, J. Geophys. Res., 113, D16S39, doi:10.1029/2007JD009168, 2008.

Kumar, R., Naja, M., Venkataramani, S., and Wild, O.: Variations in surface ozone at Nainital, a high altitude site in the Central Himalayas, J. Geophys. Res., 115, D16302, doi:10.1029/2009JD013715, 2010.

Kumar, R., Naja, M., Pfister, G. G., Barth, M. C., Wiedinmyer, C., and Brasseur, G. P.: Simulations over South Asia using the Weather Research and Forecasting model with Chemistry (WRFChem): chemistry evaluation and initial results, Geosci. Model Dev., 5, 619-648, doi:10.5194/gmd-5-619-2012, 2012.

Kumar, R., Barth, M. C., Pfister, G. G., Naja, M., and Brasseur, G. P.: WRF-Chem simulations of a typical pre-monsoon dust storm in northern India: influences on aerosol optical properties and radiation budget, Atmos. Chem. Phys., 14, 2431-2446, doi:10.5194/acp-14-2431-2014, 2014.

Lau, K. M., Kim, M. K., and Kim, K. M.: Asian summer monsoon anomalies induced by aerosol direct forcing: The role of the Tibetan Plateau, Clim. Dynam., 26, 855-864, doi:10.1007/s00382006-0114-z, 2006.

Levin, Z., Ganor, E., and Gladstein, V.: The effects of desert particles coated with sulfate on rain formation in the eastern Mediterranean, J. Appl. Meteorol., 35, 1511-1523, 1996.

Li, L., Chen, Z. M., Zhang, Y. H., Zhu, T., Li, J. L., and Ding, J.: Kinetics and mechanism of heterogeneous oxidation of sulfur dioxide by ozone on surface of calcium carbonate, Atmos. Chem. Phys., 6, 2453-2464, doi:10.5194/acp-6-2453-2006, 2006.

Liu, Y., Gibson, E. R., Cain, J. P., Wang, H., Grassian, V. H., and Laskin, A: Kinetic Study of Heterogeneous Reactions of $\mathrm{CaCO}_{3}$ Particles with $\mathrm{HNO}_{3}$ as a Function of Relative Humidity Using Single Particle Analysis, J. Phys. Chem. A, 112, 1561-1571, 2008.

Lo, J. C.-F., Yang, Z.-L., and Pielke Sr., R. A.: Assessment of three dynamical climate downscaling methods using the Weather Researchand Forecasting (WRF) model, J. Geophys. Res., 113, D09112, doi:10.1029/2007JD009216, 2008.

Madronich, S. and Weller, G.: Numerical integration errors in calculated tropospheric photodissociation rate coefficients, J. Atmos. Chem., 10, 289-300, 1990.

Martin, R. V., Jacob, D. J., Yantosca, R. M., Chin, M., and Ginoux, P.: Global and regional decreases in tropospheric oxidants from photochemical effects of aerosols, J. Geophys. Res., 108, 4097, doi:10.1029/2002JD002622, 2003.

Michel, A. E., Usher, C. R., and Grassian, V. H., Heterogeneous and catalytic uptake of ozone on mineral oxides and dusts: A Knudsen cell investigation, Geophys. Res. Lett., 29, 1665, doi:10.1029/2002GL014896, 2002.
Miller, R. L., Tegen, I., and Perlwitz, J.: Surface radiative forcing by soil dust aerosols and the hydrologic cycle, J. Geophys. Res., 109, D04203, doi:10.1029/2003JD004085, 2004.

Mlawer, E. J., Taubman, S., Brown, P., Iacono, M., and Clough, S.: Radiative transfer for inhomogenous atmosphere: RRTM, avalidated correlated-k model for the long-wave, J. Geophys. Res., 102, 16663-16682, doi:10.1029/97JD00237, 1997.

Pant, P., Hegde, P., Dumka, U. C., Satheesh, S. K., Moorthy, K. K., Saha, A., and Srivastava, M . K.: Aerosol characteristics at a high-altitude location in central Himalayas: Optical properties and radiative forcing, J. Geophys. Res., 111, D17206, doi:10.1029/2005JD006768, 2006.

Peterson, J. T.: Measurements of atmospheric aerosols and infrared radiation over northwest India and their interrelationship, $\mathrm{Ph} . \mathrm{D}$. thesis, 165pp., Dep. Of Meteorol., Univ. of Wisconsin, Madison, Wisconsin, 1968.

Pfister, G. G., Parrish, D. D., Worden, H., Emmons, L. K., Edwards, D. P., Wiedinmyer, C., Diskin, G. S., Huey, G., Oltmans, S. J., Thouret, V., Weinheimer, A., and Wisthaler, A.: Characterizing summertime chemical boundary conditions for airmasses entering the US West Coast, Atmos. Chem. Phys., 11, 1769-1790, doi:10.5194/acp-11-1769-2011, 2011.

Pozzoli, L., Bey, I., Rast, S., Schultz, M. G., Stier, P., and Feichter, J.: Trace gas and aerosol interactions in the fully coupled model of aerosol-chemistry-climate ECHAM5HAMMOZ: 1. Model description and insights from the spring 2001 TRACE-P experiment, J. Geophys. Res., 113, D07308, doi:10.1029/2007JD009007, 2008.

Pradhan, M., Kyriakou, G., Archibald, A. T., Papageorgiou, A. C., Kalberer, M., and Lambert, R. M.: Heterogeneous uptake of gaseous hydrogen peroxide by Gobi and Saharan dust aerosols: a potential missing sink for $\mathrm{H}_{2} \mathrm{O}_{2}$ in the troposphere, Atmos. Chem. Phys., 10, 7127-7136, doi:10.5194/acp-10-7127-2010, 2010.

Prasad, A. K. and Singh, R. P.: Changes in aerosol parameters during major dust storm events (2001-2005) over the Indo-Gangetic Plains using AERONET and MODIS data, J. Geophys. Res., 112, D09208, doi:10.1029/2006JD007778, 2007.

Preszler Prince, A., Kleiber, P., Grassian, V. H., and Young, M. A.: Heterogeneous interactions of calcite aerosol with sulfur dioxide and sulfur dioxide nitric acid mixtures, Phys. Chem. Chem. Phys., 9, 3432-3439, 2007.

Sagar, R., Kumar, B., Dumka, U. C., Moorthy, K. K., and Pant, P.: Characteristics of aerosol optical depths over Manora Peak: A high-altitude station in the central Himalayas, J. Geophys. Res., 109, D06207, doi:10.1029/2003JD003954, 2004.

Sarangi, T., Naja, M., Ojha, N., Kumar, R., Lal, S., Venkataramani, S., Kumar, A., Sagar, R., and Chandola, H. C.: First simultaneous measurements of ozone, $\mathrm{CO}$ and $\mathrm{NO}_{\mathrm{y}}$ at a high altitude regional representative site in the central Himalayas, J. Geophys. Res.Atmos., 119, 1592-1611, doi:10.1002/2013JD020631, 2014.

Seinfeld, J. H., Carmichael, G., Arimoto, R., Conant, W. C., Brechtel, F. J., Bates, T. S., Cahill, T. A., Clarke, A. D., Doherty, S. J., Flatau, F. J., Huebert, B. J., Kim, J., Markowicz, K. M., Quinn, P. K., Russell, L. M., Russell, P. B., Shimizu, A., Y., Song, C. H., TanShag, Y., Uno, I., Vogelmann, A. M., Weber, R. J., Woo, J., and Zhang, X. Y.: ACE-ASIA, Regional climatic and atmospheric chemical effects of Asian dust and pollution, B. Am. Meteorol. Soc., 85, 367-380, 2004. 
Skamarock, W. C., Klemp, J. B., Dudhia, J., Gill, D. O., Barker, D. M., Wang, W., and Powers, J. G.: A description of the advancedresearch WRF version 2, NCAR Tech. Note, NCAR/TN468+STR, Natl. Cent. for Atmos. Res., Boulder, Colo, available at: http://wrf-model.org/wrfadmin/publications.php (last access: 30 June 2014), 2008.

Tang, Y., Carmichael, G. R., Kurata, G., Uno, I.,Weber, R. J., Song, C.-H., Guttikunda, S. K., Woo, J.-H., Streets, D. G., Wei, C., Clarke, A. D., Huebert, B., and Anderson, T. L.: Impacts of dust on regional tropospheric chemistry during the ACE-Asia experiment: A model study with observations, J. Geophys. Res., 109, D19S21, doi:10.1029/2003JD003806, 2004.

Thompson, G., Rasmussen, R. M., and Manning, K.: Explicit forecasts of winter precipitation using an improved bulk microphysicsscheme, Part I: Description and sensitivity analysis, Mon. Weather Rev., 132, 519-542, 2004.

Tie, X., Madronich, S., Walters, S., Edwards, D. P., Ginoux, P., Mahowald, N., Zhang, R., Lou, C., and Brasseur, G.: Assessment of the global impact of aerosols on tropospheric oxidants, J. Geophys. Res., 110, D03204, doi:10.1029/2004JD005359, 2005.

Underwood, G. M., Song, C. H., Phadnis, M., Carmichael, G. R., and Grassian, V. H.: Heterogeneous reactions of $\mathrm{NO}_{2}$ and $\mathrm{HNO}_{3}$ on oxides and mineral dust: a combined laboratory and modeling study, J. Geophys. Res., 106, 18055-18066, 2001.

Usher, C. R., Michel, A. E., Stec, D., and Grassian, V. H.: Laboratory Studies of Ozone Uptake on Processed Mineral Dust, Atmos. Environ., 37, 5337-5347, doi:10.1016/j.atmosenv.2003.09.014, 2003.

Wagner, C., Hanisch, F., Holmes, N., de Coninck, H., Schuster, G., and Crowley, J. N.: The interaction of $\mathrm{N}_{2} \mathrm{O}_{5}$ with mineral dust: aerosol flow tube and Knudsen reactor studies, Atmos. Chem. Phys., 8, 91-109, doi:10.5194/acp-8-91-2008, 2008.

Wang, K., Zhang, Y., Nenes, A., and Fountoukis, C.: Implementation of dust emission and chemistry into the Community Multiscale Air Quality modeling system and initial application to an Asian dust storm episode, Atmos. Chem. Phys., 12, 1020910237, doi:10.5194/acp-12-10209-2012, 2012.
Wiedinmyer, C., Akagi, S. K., Yokelson, R. J., Emmons, L. K., AlSaadi, J. A., Orlando, J. J., and Soja, A. J.: The Fire INventory from NCAR (FINN): a high resolution global model to estimate the emissions from open burning, Geosci. Model Dev., 4, 625641, doi:10.5194/gmd-4-625-2011, 2011.

Ying, Z., Tie, X., Madronich, S., Li, G., and Massie, S.: Simulation of regional dust and its effect on photochemistry in the Mexico City area during MILAGRO experiment, Atmos. Environ., 45, 2549-2558, 2011.

Zhang, Q., Streets, D. G., Carmichael, G. R., He, K. B., Huo, H., Kannari, A., Klimont, Z., Park, I. S., Reddy, S., Fu, J. S., Chen, D., Duan, L., Lei, Y., Wang, L. T., and Yao, Z. L.: Asian emissions in 2006 for the NASA INTEX-B mission, Atmos. Chem. Phys., 9, 5131-5153, doi:10.5194/acp-9-5131-2009, 2009.

Zhang, Y. and Carmichael, G. R.: The role of mineral aerosol in tropospheric chemistry in East Asia - a model study, J. Appl. Meteorol., 38, 353-366, 1999.

Zhang, Y., Sunwoo, Y., Kotamarthi, V., and Carmichael, G. R.: Photochemical oxidant processes in the presence of dust: An evaluation of the impact of dust on particulate nitrate and ozone formation, J. Appl. Meteorol., 33, 813-824, 1994.

Zhao, C., Liu, X., Ruby Leung, L., and Hagos, S.: Radiative impact of mineral dust on monsoon precipitation variability over West Africa, Atmos. Chem. Phys., 11, 1879-1893, doi:10.5194/acp11-1879-2011, 2011.

Zhou, Y., Brunner, D., Boersma, K. F., Dirksen, R., and Wang, P.: An improved tropospheric $\mathrm{NO}_{2}$ retrieval for OMI observations in the vicinity of mountainous terrain, Atmos. Meas. Tech., 2, 401-416, doi:10.5194/amt-2-401-2009, 2009.

Zhu, S., Butler, T., Sander, R., Ma, J., and Lawrence, M. G.: Impact of dust on tropospheric chemistry over polluted regions: a case study of the Beijing megacity, Atmos. Chem. Phys., 10, 38553873, doi:10.5194/acp-10-3855-2010, 2010. 